Contract Program or

Project Title:

Subject of this Document

Type of Document:

Authors:

Date of Document:

Responsible NRC Individual and NRC Office or Division
Heavy-Section Steel Technology (HSST) Program Engineering Technology Division

Development of a Methodology for the Assessment of Shallow-Flaw Fracture in Nuclear Reactor Pressure Vessels: Generation of Biaxial ShallowFlaw Fracture Toughness Data

Letter Report

W. J. McAfee

B. R. Bass

J. W. Bryson

July 1998

M. G. Vassilaros (301) 415-6000

Division of Engineering Technology, U.S. Nuclear Regulatory Commission
DUL 221998

OSTI

Prepared for the

U.S. Nuclear Regulatory Commission

Washington, D.C. 20555-0001

Under Interagency Agreement DOE 1886-N011-9B

NRC FIN B01 19

OAK RIDGE NATIONAL LABORATORY

Oak Ridge, Tennessee 37831-8056

managed by

LOCKHEED MARTIN ENERGY RESEARCH CORP.

for the

U. S. DEPARTMENT OF ENERGY

under Contract No. DE-AC05-96OR22464 


\section{DISCLAIMER}

This report was prepared as an account of work sponsored by an agency of the United States Government. Neither the United States Government nor any agency thereof, nor any of their employees, makes any warranty, express or implied, or assumes any legal liability or responsibility for the accuracy, completeness, or usefulness of any information, apparatus, product, or process disclosed, or represents that its use would not infringe privately owned rights. Reference herein to any specific commercial product, process, or service by trade name, trademark, manufacturer, or otherwise does not necessarily constitute or imply its endorsement, recommendation, or favoring by the United States Government or any agency thereof. The views and opinions of authors expressed herein do not necessarily state or reflect those of the United States Government or any agency thereof. 


\section{DISCLAIMER}

Portions of this document may be illegible in electronic image products. Images are produced from the best available original document. 


\title{
Development of a Methodology for the Assessment of Shallow-Flaw Fracture in Nuclear Reactor Pressure Vessels: Generation of Biaxial Shallow-Flaw Fracture Toughness Data
}

\author{
W. J. McAfee, B. R. Bass, and J. W. Bryson \\ Oak Ridge National Laboratory \\ Oak Ridge, Tennessee
}

Date Published-July 1998

Prepared for the

U.S. Nuclear Regulatory Commission

Office of Nuclear Regulatory Research

Under Interagency Agreement DOE 1886-N011-9B

NRC JCN B0119

Prepared by the

OAK RIDGE NATIONAL LABORATORY

Oak Ridge, Tennessee 37831-8056

managed by

LOCKHEED MARTIN ENERGY RESEARCH CORP.

for the

U. S. DEPARTMENT OF ENERGY

under Contract No. DE-AC05-96OR22464 


\title{
Development of a Methodology for the Assessment of Shallow-Flaw Fracture in Nuclear Reactor Pressure Vessels: Generation of Biaxial Shallow-Flaw Fracture Toughness Data
}

\author{
W. J. McAfee, B. R. Bass, and J. W. Bryson \\ Oak Ridge National Laboratory
}

\begin{abstract}
A technology to determine shallow-flaw fracture toughness of reactor pressure vessel (RPV) steels is being developed for application to the safety assessment of RPVs containing postulated shallow-surface flaws. Shallow-flaw fracture toughness of RPV material has been shown to be higher than that for deep flaws, because of the relaxation of crack-tip constraint. Previously, uniaxial full-thickness clad beam tests were used to quantify this shallow-flaw effect in specimens (taken from an RPV of a canceled nuclear plant) which are typical of RPV wall thickness and material properties. However, the uniaxial beams did not address the increased constraint due to biaxial loading found in an operating RPV. Cruciform beam specimens developed at the Oak Ridge National Laboratory (ORNL) introduce far-field, out-of-plane biaxial stress components in the test section that approximates the non-linear stresses resulting from pressurizedthermal-shock (PTS) loading of an RPV. The biaxial stress component has the potential to increase stress triaxiality (constraint) at the crack tip, and thereby reduce the shallow-flaw fracture toughness enhancement. The cruciform specimen permits controlled application of biaxial loading ratios, resulting in controlled variation of crack-tip constraint.
\end{abstract}

Matrices of cruciform beam tests were developed to investigate and quantify the effects of temperature, flaw depth, biaxial loading, and specimen size on fracture initiation toughness of twodimensional (constant depth), shallow-surface flaws. The specimens for this test sequence were fabricated using a heat treated material with an elevated yield strength typical of irradiated RPV material. Tests were conducted under biaxial load ratios ranging from 0:1 (uniaxial) to 1:1 (full biaxial). The test matrices, when completed, will provide a basis for developing a shallow-flaw fracture toughness methodology for extrapolation of laboratory-size specimen test data to evaluation of RPV behavior.

This report describes the preliminary test results for a series of cruciform specimens with a uniform depth surface flaw. These specimens are all of the same size with the same depth flaw. Temperature and biaxial load ratio are the independent variables. These tests demonstrated that biaxial loading could have a pronounced effect on shallow-flaw fracture toughness in the lower transition temperature region for RPV materials. Through that temperature range, the effect of full biaxial (1:1) loading on uniaxial, shallow-flaw toughness varied from no effect near the lower shelf to a reduction of approximately $58 \%$ at higher temperatures.

\section{Introduction}

A technology is being developed within the Heavy-Section Steel Technology (HSST) Program to determine shallow-flaw fracture toughness of reactor pressure vessel (RPV) steels for application to the safety assessment of RPVs. The principal elements that influence constraint of postulated shallow-surface flaws in an RPV are flaw geometry, flaw depth, material properties, and type of loading. Quantification of the effects of these four elements on constraint and fracture toughness 
has been the focus of substantial research in recent years. The mean shallow-flaw fracture toughness obtained from RPV material has been shown to be higher than that for deep-flaws, because of the relaxation of crack-tip constraint [1]. Previously, uniaxial full-thickness clad beam tests [2] were used to quantify this shallow-flaw effect in specimens (taken from an RPV of a canceled nuclear plant) which are typical of RPV wall thickness and material properties. However, the uniaxial beams did not address biaxial loading effects found in an operating RPV. Cruciform beam specimens [3] developed at the Oak Ridge National Laboratory (ORNL) introduce far-field, out-of-plane biaxial stress components in the test section that approximates the non-linear stresses resulting from pressurized-thermal-shock (PTS) loading of an RPV. The out-of-plane biaxial stress component has the potential to increase constraint at the crack tip, and thereby reduce the shallow-flaw fracture toughness enhancement. The cruciform specimen permits controlled application of biaxial loading, resulting in controlled variation of crack-tip constraint.

Investigation of the effect of biaxial (out-of-plane) loading as an independent parameter in the determination of fracture toughness was first performed by Aurich et al. [4] using several different test specimens. From these test results, Aurich asserted that uniaxially loaded specimens tested under plane-strain conditions would not necessarily give a lower-bound toughness. His observations were primarily phenomenologically based and no hypothesis was advanced as to the cause of biaxial effects.

Biaxial loading has been identified as a condition requiring quantification for PTS evaluations, and a systematic approach to the problem was proposed by Pennell [5]. His preliminary interpretation of the potential for this "biaxial effect" was based on recognition that, under PTS loading, the induced biaxial or out-of-plane loading produces a strain component parallel to the flaw front (for a uniform depth 2-D flaw) greater than what would be produced under plane-strain conditions for the same level of crack-mouth-opening driving force. Pennell further hypothesized that, since loss of plane-strain constraint results in a Poisson ratio-induced contraction along the flaw front and an associated increase in fracture toughness, an increase in the out-of-plane loading, with commensurate increase in constraint, had the potential for reduction of fracture toughness, possibly below the plane-strain value. In other words, as observed by Aurich [4], fracture toughness data obtained under plane-strain conditions may not represent lower-bound values. To evaluate this hypothesis, analyses of the potential effect of biaxial loading on the calculated critical $\mathrm{K}_{\mathrm{Ic}}$ were performed. Use of a generalized plane-strain flaw-tip model [6] and a stress-based dual-parameter model [7] predicted that there would be little, if any, reduction in fracture toughness caused by outof-plane loading. It was observed from these analyses, however, that an increase in the biaxial loading resulted in a decrease in the size of the plastic zone around the flaw tip [6]. The reduction in plastic zone size was most pronounced along the direction ahead of the flaw tip, which causes 
the plastic zone to assume a butterfly shape with symmetry about the flaw plane. The prediction of little or no effect of biaxial loading on toughness obtained from the above analyses would normally have been sufficient to lay this issue to rest.

However, Pennell [8] observed that, although the above analytical results were valid in the method of implementation, they were not independent in the sense that both were based on a detailed definition of the near-tip stress-strain field where strains are very high. He took an alternate path to investigate the possible effects of biaxial loading on fracture toughness. The elastic stresses developed on the plane of crack propagation of an edge notch in a finite-thickness plate for planestress, plane-strain, and biaxial loading constraint conditions were modeled. The location of the plastic zone boundary was determined (location ahead of the flaw tip where von Mises stress/yield stress $=1.0$ ) for each of these cases. From these analyses, it was observed that the calculated plastic zone size for the biaxial case was only $60 \%$ of the size for plane-strain conditions. Additionally, at this load point, the ratio of hydrostatic stress to von Mises equivalent stress was increased by $86 \%$ for biaxial loading compared to plane-strain conditions. These results indicated behavior at the plastic zone boundary that was not reflected in the detailed, stress-based analyses [6]. His scoping calculations were extended to an evaluation of the relationship between fracture ductility and fracture toughness [8]. Using an equation developed by Weiss [9] relating fracture toughness and stress-state dependent fracture strain, it was estimated that biaxial loading could reduce fracture toughness to $47 \%$ of that determined under full plane-strain constraint conditions [8]. These simplified investigations demonstrated the need for further analytical and experimental work to resolve the effect of biaxial loading on toughness and to evaluate the role of fracture ductility in dual-parameter correlations for estimating fracture toughness.

The HSST Program thus defined and performed a limited, "development" matrix of beam tests to investigate the effect of biaxial loading on fracture toughness. The material selected was an A 533 Grade B (A 533 B) Class-1 steel that had been used in a prior investigation of the effect of shallow flaws on fracture toughness [1]. This "low-yield-strength" material $[\approx 380 \sqrt{\mathrm{MPa}}(55 \mathrm{ksi})$ at room temperature] was used primarily because a substantial fracture toughness data base existed for both deep and shallow flaws and would provide a baseline for evaluating biaxial loading effects. Part of this initial test effort was the design and validation of a special cruciform fracture toughness specimen for tests in bending. The bending stresses developed in the test section produce a linear approximation to the non-linear stresses produced during RPV PTS loading, Fig. 1. This cruciform specimen permits controlled application of biaxial loading ratios resulting in controlled variations of crack-tip constraint for shallow-surface flaws, see Fig. 2. The biaxial load ratio is defined as $P_{T} / P_{L}$, where $P_{T}$ is the total load applied to the transverse beam arms and $P_{L}$ is the total 


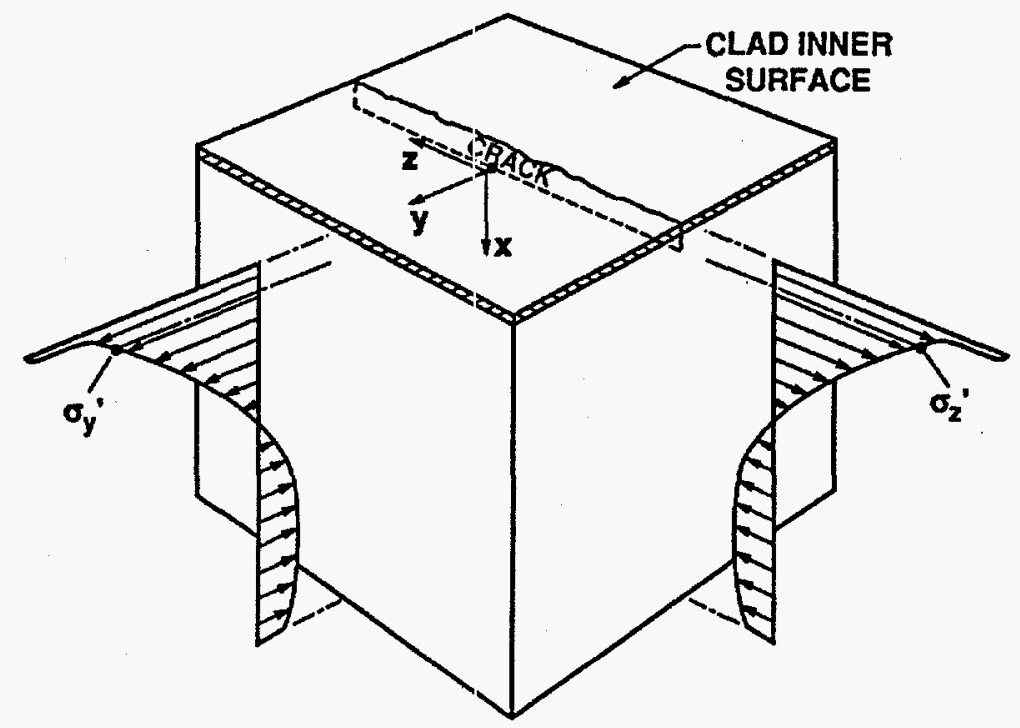

Fig. 1. PTS loading produces biaxial stress in an RPV wall with one of the principal stresses aligned parallel with the tip of the constant-depth shallow-surface flaw.

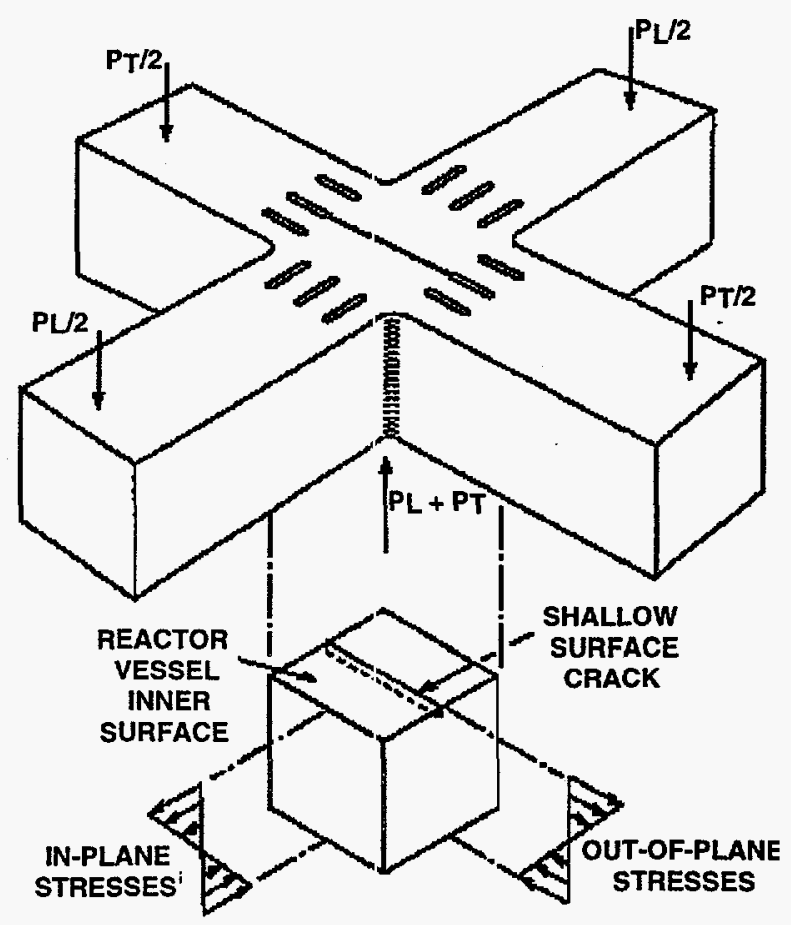

Fig. 2. Conceptual features of the cruciform shallow-flaw biaxial fracture toughness test specimen. 
load applied to the longitudinal arms. A special test fixture was also designed and fabricated permitting testing under uniaxial loading $\left(\mathrm{P}_{\mathrm{T}} / \mathrm{P}_{\mathrm{L}}\right.$ ratio of $\left.0: 1\right)$ and two biaxial loading ratios $\left(\mathrm{P}_{\mathrm{T}} / \mathrm{P}_{\mathrm{L}}\right.$ ratios of $0.6: 1$ and $1: 1$ ). The specimen and test fixture has been described extensively in prior HSST publications [3,10-11].

For the development matrix, all tests were performed at a normalized temperature of T-NDT $=$ $-10^{\circ} \mathrm{C}\left(-18^{\circ} \mathrm{F}\right)$, and the results are shown in Fig. 3. This plot shows fracture toughness as a function of the applied biaxial load ratio. For the uniaxial load case, the toughness values obtained were well above those for deep-flaw specimens for this material at this temperature, clearly demonstrating the shallow-flaw effect (loss of constraint). These results also showed that increasing the biaxial load ratio results in a decrease in the lower-bound fracture toughness, although the lowest data point does not fall below the deep-flaw data set.

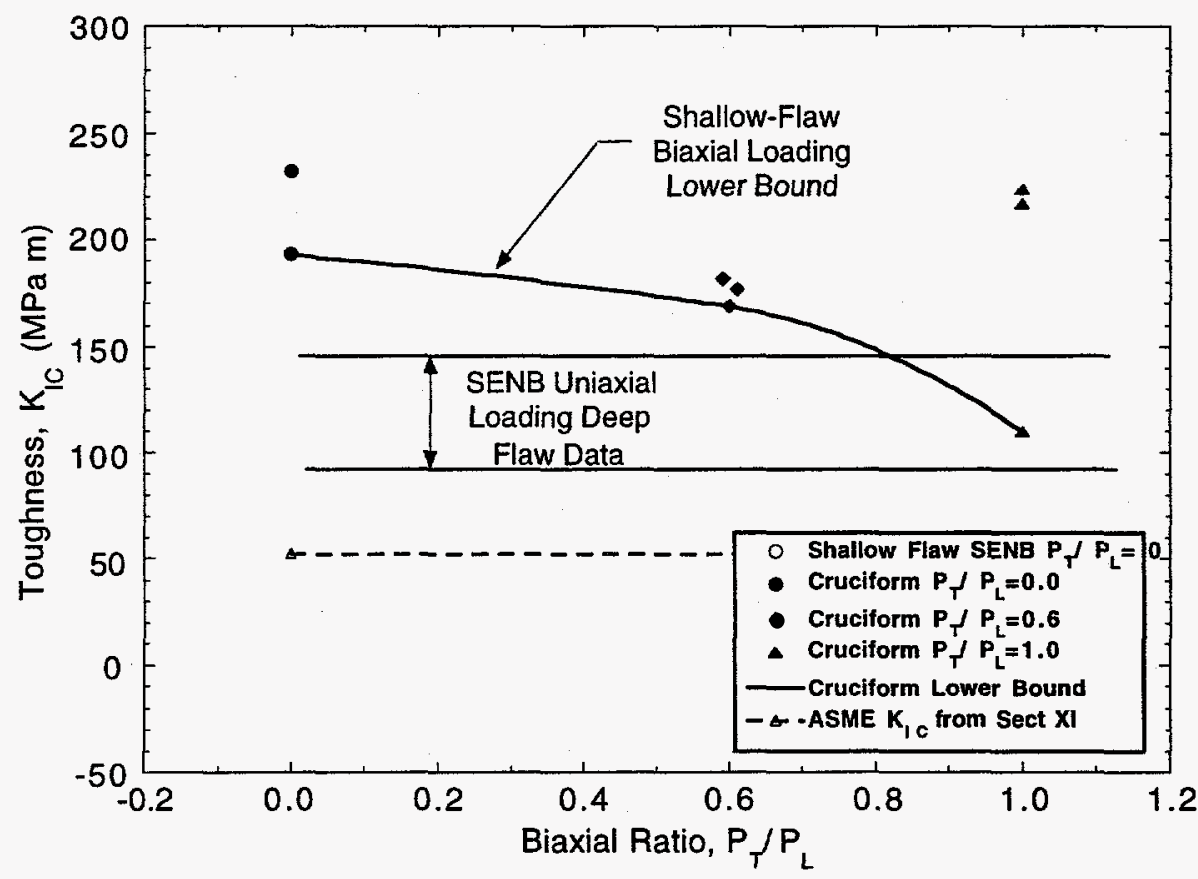

Fig. 3. Biaxial loading effects on shallow-flaw fracture toughness of low-yield strength A 533 B steel compared to deep-flaw fracture toughness for same material.

For the verification phase of biaxial testing, matrices of cruciform beam tests were defined to evaluate biaxial loading effects on the fracture toughness of 2-D (infinite-length) and 3-D (finitelength) shallow-surface flaws. An A 533 B material with elevated yield strength was fabricated into cruciform specimens incorporating 2-D flaws and tested with load ratio and temperature as 
independent parameters. In addition, cruciform clad beam specimens containing semi-elliptical finite-length (3-D) surface flaws were fabricated from an RPV shell segment available from a canceled pressurized-water-reactor plant (the plant was canceled during construction, and the vessel was never in service). A preliminary set of tests and analyses for unclad biaxially-loaded cruciform specimens that contain two-dimensional (2-D) surface flaws has been completed and the results are reported herein. Tests were run with biaxial load ratios, $\mathrm{P}_{\mathrm{T}} / \mathrm{P}_{\mathrm{L}}$, of 0:0, 0.6:1, and 1:1. Five different temperatures through the transition temperature region for toughness were sampled in this series of tests. The test program, test results, and analyses are discussed in the following sections. Results obtained from biaxial testing of the RPV shell material are presented in Ref. 12.

\section{Material Preparation and Characterization}

HSST Plate 14 (A533B material) was used as the source material for the biaxial-loading constraint verification test specimens containing 2-D flaws. This plate was selected primarily because of a high carbon content, which made it more responsive to increasing the yield strength by heattreating. The ASME Code [13] requirements and results for ladle and laboratory chemistry analysis are shown in Table 1. The carbon content of Plate 14 is near the maximum allowable for A533B material. The intent was to heat treat the base material to achieve an elevated yield strength approximating that for a typical radiation-sensitive RPV steel irradiated to a fluence of $1.5 \times 10^{19} \mathrm{n} / \mathrm{cm}^{2}(>1 \mathrm{MeV})$. The heat-treating was performed successfully, providing a room temperature yield stress in the range desired [14]. Fabrication of the cruciform specimens has been described in Ref. 15.

Characterization of the heat-treated material was performed to provide verification of properties and to provide input to the 3-D finite-element modeling and analyses. Tensile, Charpy, drop-weight, and 1/2T compact tension specimens were tested [15]. From Charpy V-notch (CVN) testing, $T_{C v}$ was determined to be $56^{\circ} \mathrm{C}\left(132^{\circ} \mathrm{F}\right)$ and drop-weight nil-ductility temperature (NDT) was found to be $40^{\circ} \mathrm{C}\left(104^{\circ} \mathrm{F}\right)$. Thus, NDT controlled the reference temperature and $\mathrm{RT}_{\mathrm{NDT}}=40^{\circ} \mathrm{C}\left(104^{\circ} \mathrm{F}\right)$. NDT was used to establish the tensile test temperatures and as a starting point for the cruciform test temperature. A comparison was made between the Charpy results for Plate 14 and data from the HSSI Fifth Irradiation Series Weld 73W [16] in the irradiated $\left[1.51 \times 10^{19} \mathrm{n} / \mathrm{cm}^{2}(>1 \mathrm{MeV})\right]$ condition (see Fig. 4). From this comparison, it was observed that the trend of the Charpy data for Plate 14 very nearly matched that of the irradiated $73 \mathrm{~W}$ [16]. It can then be concluded that impact properties of Plate 14 very much resemble those of an irradiated material, and the heat treatment was successful in providing the type of material desired. 
Table 1. Chemical Analysis of HSST Plate 14

\begin{tabular}{|c|c|c|c|}
\hline Element & $\begin{array}{l}\text { Requirement* } \\
\text { (wt. percent) }\end{array}$ & $\begin{array}{l}\text { Ladle Analysis } \\
\text { (wt. percent) }\end{array}$ & $\begin{array}{l}\text { Laboratory } \\
\text { Analysis } \\
\text { (wt. percent) }\end{array}$ \\
\hline Carbon & $0.25, \max$ & 0.215 & 0.220 \\
\hline Manganese & $1.15-1.500$ & 1.400 & 1.440 \\
\hline Phosphorous & 0.035 & 0.010 & 0.005 \\
\hline Sulfur & $0.035, \max$ & 0.005 & 0.003 \\
\hline Silicon & $0.150-0.400$ & 0.220 & 0.200 \\
\hline Nickel & $0.400-0.700$ & 0.655 & 0.620 \\
\hline Chromium & & & 0.060 \\
\hline Molybdenum & $0.450-0.600$ & 0.560 & 0.560 \\
\hline Vanadium & & & 0.001 \\
\hline Columbium & & & $<0.001$ \\
\hline Titanium & & & $<0.001$ \\
\hline Cobalt & & 0.019 & 0.021 \\
\hline Copper & & 0.070 & 0.05 \\
\hline Aluminum & & & 0.014 \\
\hline Boron & & & $<0.001$ \\
\hline Tungsten & & & $<0.01$ \\
\hline Antimony & & & $<0.002$ \\
\hline Arsenic & & & 0.028 \\
\hline Tin & & & 0.004 \\
\hline Zirconium & & & $<0.001$ \\
\hline Lead & & & $<0.002$ \\
\hline Nitrogen & & & 0.008 \\
\hline Oxygen & & & 0.003 \\
\hline
\end{tabular}

$*$ Requirements for chemistry of heat of material ${ }^{13}$

ASTM standard 6.35-mm (0.25-in.) gage diameter tensile specimens were machined from material near the midplane of the plate and at four locations through the half thickness. The tensile characterization results are summarized in Table 2, grouped according to test temperature. Tests 


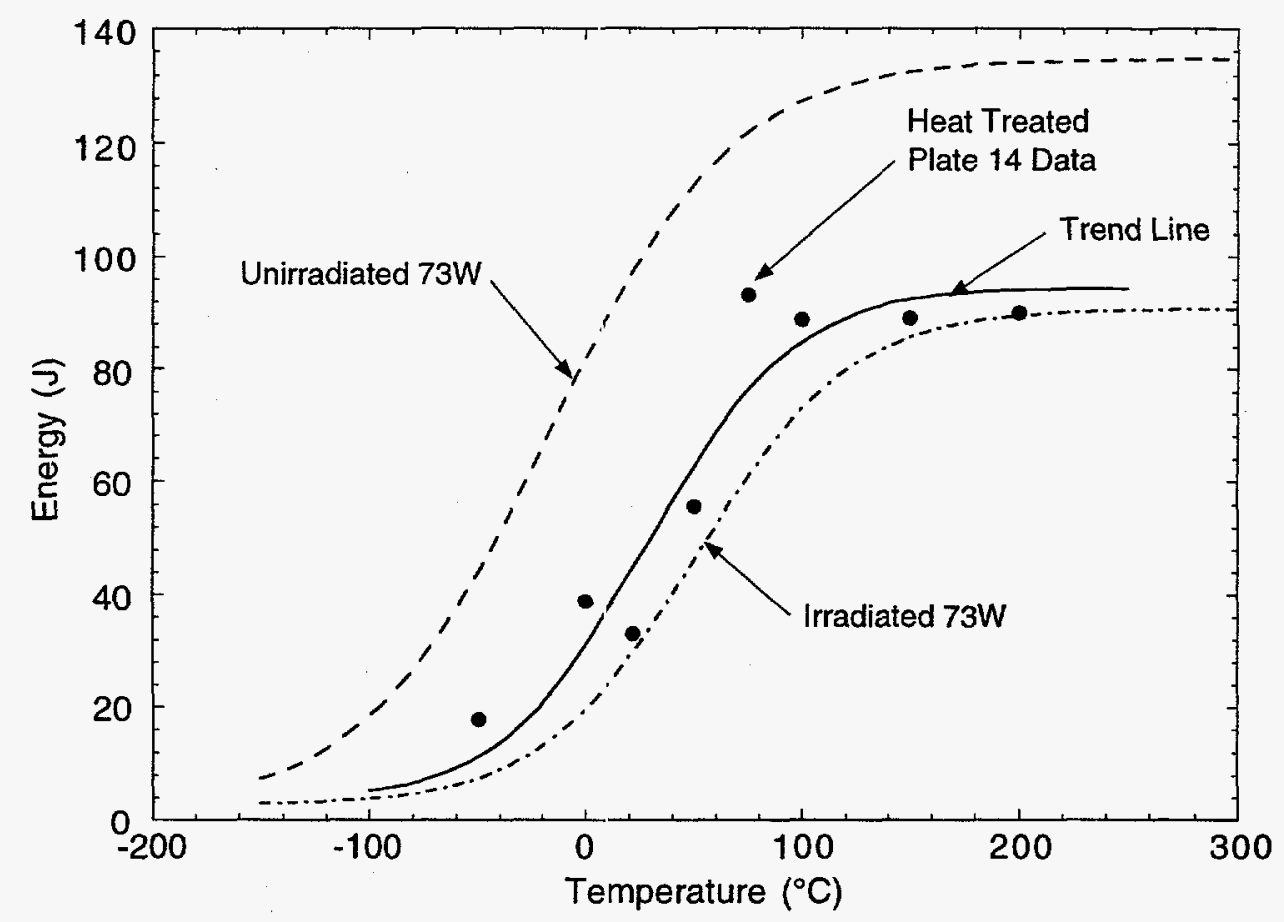

Fig. 4. Comparison of Charpy curves from heat-treated Plate 14 material with that from irradiated $73 \mathrm{~W}$ material.

were performed at four different temperatures using specimens taken from a single layer near the mid-plane of the plate to characterize temperature dependency. These temperatures were NDT $\left[\mathrm{NDT}=40^{\circ} \mathrm{C}\left(104^{\circ} \mathrm{F}\right)\right],-30^{\circ} \mathrm{C}\left(-22^{\circ} \mathrm{F}\right), 10^{\circ} \mathrm{C}\left(50^{\circ} \mathrm{F}\right)$, and $60^{\circ} \mathrm{C}\left(140^{\circ} \mathrm{F}\right)$, and were selected as being the anticipated test temperature range for the cruciform specimens in the verification matrix. Four locations through the thickness of the plate were also sampled. The variation of tensile properties with both temperature and location through the plate thickness was observed to be relatively small as is shown in Figs. 5 and 6, respectively.

Eight $1 / 2 \mathrm{~T}$ compact tension specimens from a single location within the plate were tested at a temperature of $\mathrm{T}=-30^{\circ} \mathrm{C}\left(\mathrm{T}-\mathrm{NDT}=-70^{\circ} \mathrm{C}\right)$. These data were correlated using the Master curve [17] approach to determine a normalizing temperature $\mathrm{T}_{0}$ of $-45.6^{\circ} \mathrm{C}\left(50.1^{\circ} \mathrm{F}\right)$. The mean Master curve was adjusted to a $4 \mathrm{~T}$ constraint condition to represent the cruciform specimen size [15], see Fig. 7. The $4 \mathrm{~T}$ constraint curve indicated that, at $\mathrm{T}=-30^{\circ} \mathrm{C}$, the toughness should be well into the lower-transition temperature region with a relatively rapid increase in toughness and increasing plastic deformation with increasing temperature. Using this evaluation for guidance, a temperature of $\mathrm{T}=-30^{\circ} \mathrm{C}\left(-22^{\circ} \mathrm{F}\right)$ was selected for testing of the first set of six cruciform specimens. The cruciform specimens tested at this temperature were characterized by low plasticity and no 
Table 2. Summary of tensile properties for heat-treated HSST Plate 14

\begin{tabular}{|c|c|c|c|c|c|c|c|c|}
\hline $\begin{array}{l}\text { Specimen } \\
\text { Number }\end{array}$ & $\begin{array}{c}\text { Specimen } \\
\text { Center* } \\
(\mathrm{mm}) \\
\end{array}$ & $\begin{array}{c}\text { Test } \\
\text { Temperature } \\
\left({ }^{\circ} \mathrm{C}\right) \\
\end{array}$ & $\begin{array}{l}\text { Yield } \\
\text { Stress } \\
(\mathrm{MPa}) \\
\end{array}$ & $\begin{array}{c}\text { Ultimate } \\
\text { Strength } \\
(\mathrm{MPa})\end{array}$ & $\begin{array}{c}\text { Elastic } \\
\text { Modulus } \\
(\mathrm{GPa})\end{array}$ & $\begin{array}{c}\text { Uniform } \\
\text { Elongation } \\
(\%) \\
\end{array}$ & $\begin{array}{c}\text { Total } \\
\text { Elongation } \\
(\%) \\
\end{array}$ & $\begin{array}{c}\text { Reduction } \\
\text { in Area } \\
(\%)\end{array}$ \\
\hline TH01 & 12.7 & 40 & 633.0 & 796.4 & 209.6 & 5.8 & 13.7 & 50.8 \\
\hline TH02 & 31.8 & 40 & 620.3 & 778.4 & 190.0 & 6.3 & 17.1 & 60.0 \\
\hline TH03 & 50.8 & 40 & 605.1 & 768.4 & 185.4 & 6.1 & 18.4 & 63.5 \\
\hline TH04 & 69.9 & 40 & 609.2 & 761.8 & 227.6 & 5.5 & 14.8 & 62.6 \\
\hline TH05 & 12.7 & 40 & 641.4 & 806.0 & 227.1 & 6.2 & 16.3 & 53.8 \\
\hline TH06 & 31.8 & 40 & 615.7 & 769.4 & 194.7 & 5.7 & 16.9 & 58.1 \\
\hline TH07 & 50.8 & 40 & 605.3 & 761.3 & 194.2 & 6.1 & 16.7 & 58.1 \\
\hline TH08 & 69.9 & 40 & 606.7 & 760.9 & 225.8 & 5.8 & 16.7 & 61.2 \\
\hline Average & & & 617.1 & 775.3 & 206.8 & 5.9 & 16.3 & 58.5 \\
\hline TH09 & 12.7 & 60 & 627.7 & 782.9 & 211.1 & 5.1 & 15.4 & 57.3 \\
\hline TH10 & 12.7 & 60 & 634.5 & 801.6 & 204.8 & 5.0 & 13.1 & 31.6 \\
\hline Average & & & 631.1 & 792.2 & 211.1 & 5.1 & 15.4 & 44.5 \\
\hline TH11 & 12.7 & 10 & 652.9 & 828.4 & 197.3 & 6.8 & 13.2 & 50.2 \\
\hline TH12 & 12.7 & 10 & 646.5 & 817.3 & 216.2 & 6.5 & 14.2 & 32.0 \\
\hline Average & & & 649.7 & 822.8 & 197.3 & 6.7 & 13.7 & 41.1 \\
\hline TH13 & 12.7 & -30 & 668.5 & 847.9 & 224.7 & 6.5 & 18.6 & 50.0 \\
\hline
\end{tabular}

*Measured from original midplane of plate.

biaxial effect. It should be noted that $\mathrm{T}_{0}$ methodology was developed for deep-flaw, highconstraint specimens under uniaxial loading so that its application here was an extrapolation of the methodology outside its intended domain. Also, there is the question of mapping the toughness behavior of $1 / 2 \mathrm{~T}$ specimens to $4 \mathrm{~T}$ size. For whatever reasons, applicability of $\mathrm{T}_{0}$ or methodology for size adjustment, the procedures proved less than satisfactory for selection of appropriate test temperatures for the cruciform specimens. 


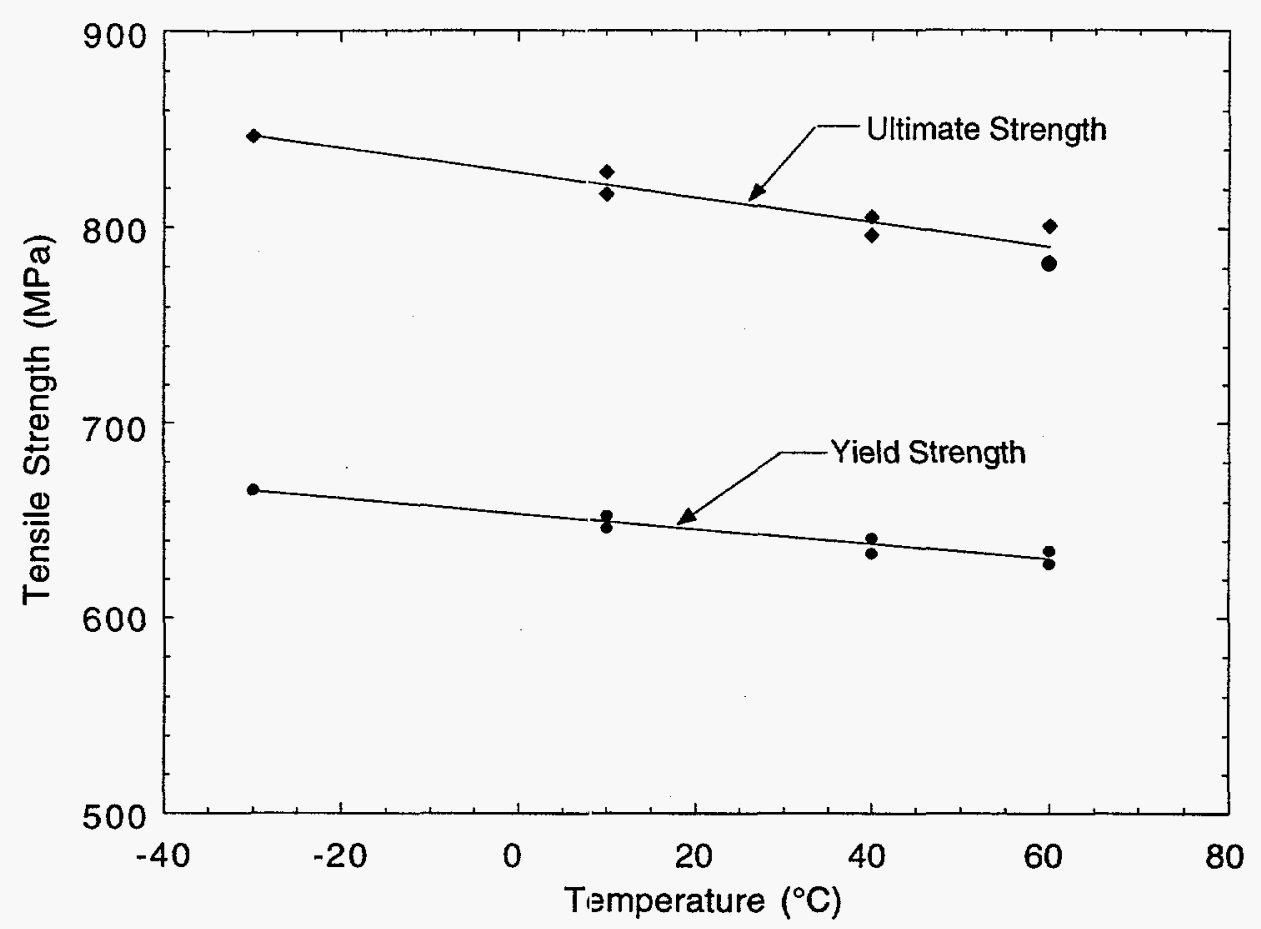

Fig. 5. Tensile properties of heat-treated Plate 14 over temperature range $-30^{\circ} \mathrm{C}\left(-22^{\circ} \mathrm{F}\right)$ to $60^{\circ} \mathrm{C}\left(140^{\circ} \mathrm{F}\right)$.

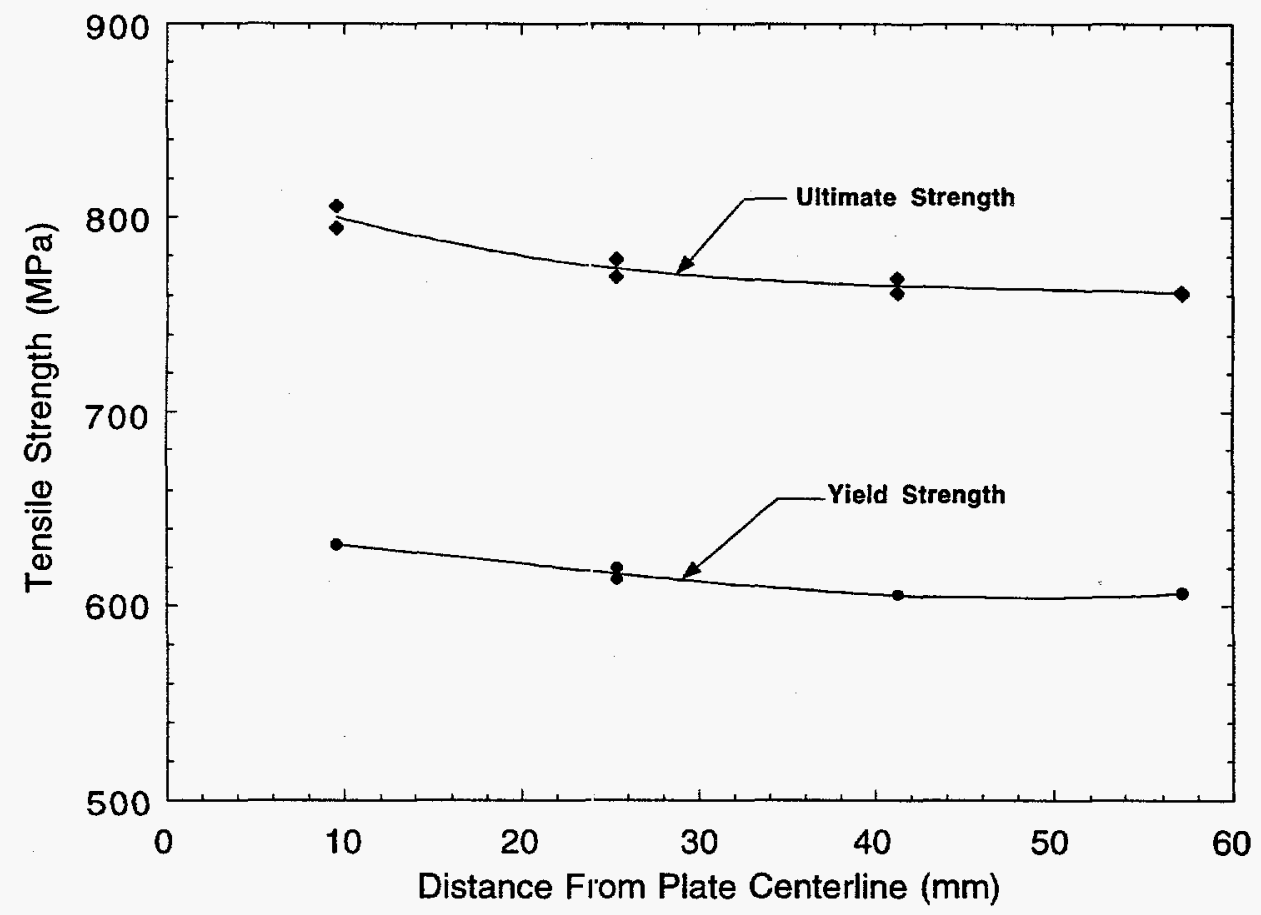

Fig. 6. Tensile properties of heat-treated Plate 14 are relatively independent of location through plate thickness [test temperature $=\mathrm{NDT}=40^{\circ} \mathrm{C}\left(104^{\circ} \mathrm{F}\right)$ ]. 


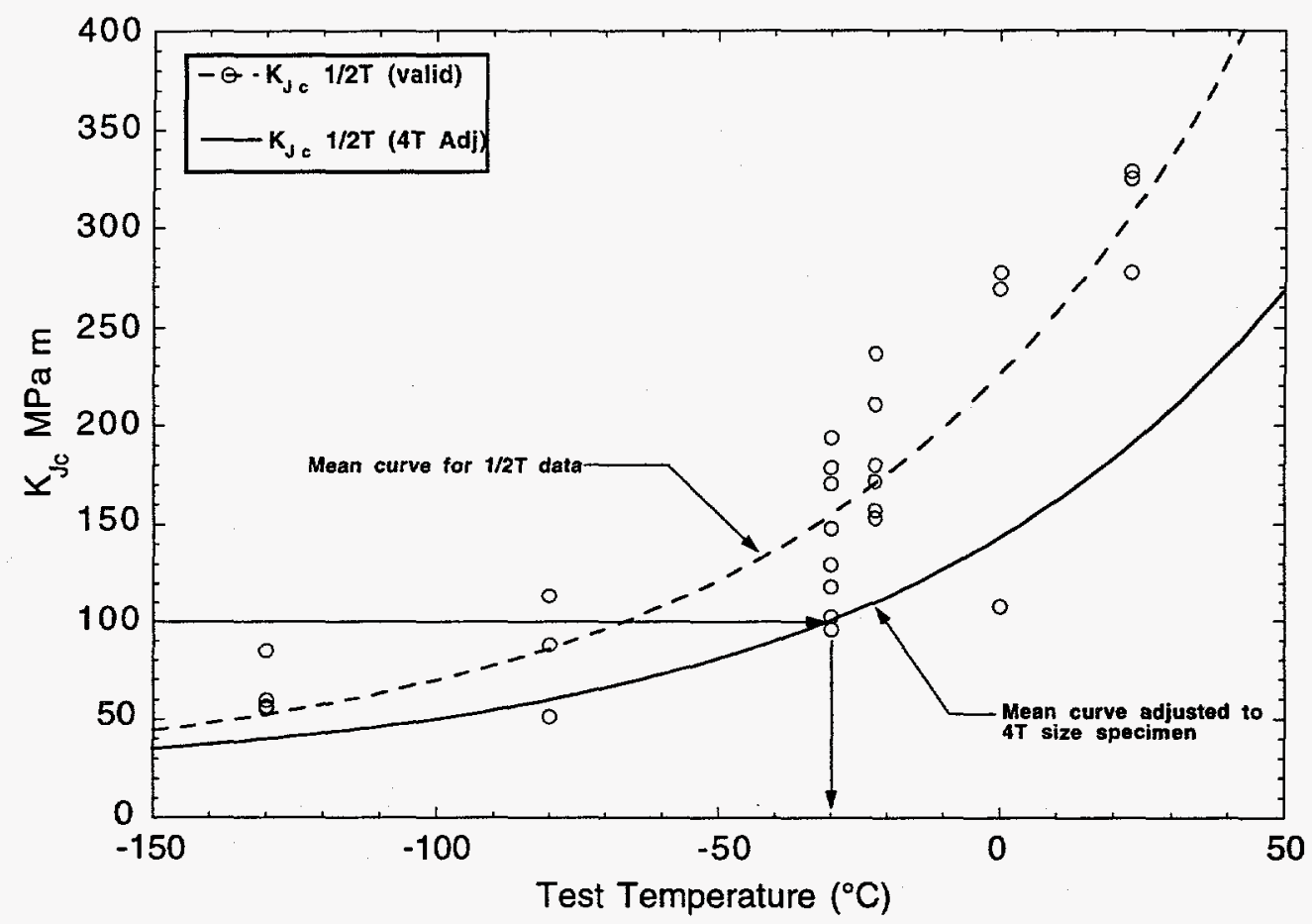

Fig. 7. "Mean" curve for fracture toughness data from 1/2T compact tension specimens and mean curve adjusted to $4 \mathrm{~T}$ size specimen. Heat-treated Plate 14 material

An additional twenty-four $1 / 2 \mathrm{~T}$ compact specimens, taken from different locations within the parent plate, were tested over the range of $-130^{\circ} \mathrm{C}$ to room temperature. All compact tension test results are shown in Fig. 8 and Table 3. For temperatures at and above $\mathrm{T}=-10^{\circ} \mathrm{C}$, some of the $1 / 2 \mathrm{~T}$ specimens did not cleave, but underwent ductile tearing that resulted in deformations to the limit of the clip gage, i.e., generation of a full J-R curve without cleavage. This was interpreted as loss of constraint for these small-scale specimens and would indicate a sharp upturn in toughness with a small increase in temperature. An exponential "mean" trend curve was fitted to these data to determine the variation of $\mathrm{K}_{\mathrm{Jc}}$ with temperature. This mean curve was then adjusted to full plane strain conditions using the Irwin $B_{\text {Ic }}$ specimen-size adjustment as modified by Merkle [18]. The adjusted mean curve exhibits a shape characteristic of the very low transition temperature region, i.e., near lower shelf, over the normalized temperature range $-175^{\circ} \mathrm{C}<\mathrm{T}$ NDT $<0^{\circ} \mathrm{C}$. The Irwin $\beta_{\mathrm{Ic}}$ curve could be interpreted, based on the predicted relative toughness values, to indicate that little biaxial effect would be observed up to normalized test temperatures of $0^{\circ} \mathrm{C}$. However, a trial cruciform specimen tested under uniaxial load at $\mathrm{T}=\mathrm{NDT}=40^{\circ} \mathrm{C}$ failed by plastic collapse, not fracture. Merkle contended that the Irwin $B_{I c}$ adjustment over-corrects for 
Table 3. Summary of $1 / 2 \mathrm{~T}$ compact tension results for heat-treated HSST Plate 14

\begin{tabular}{cccccc}
\hline $\begin{array}{c}\text { Source } \\
\text { Block }\end{array}$ & $\begin{array}{c}\text { Specimen } \\
\text { Number }\end{array}$ & $\begin{array}{c}\text { Test } \\
\text { Temperature } \\
\left({ }^{\circ} \mathrm{C}\right)\end{array}$ & $\begin{array}{c}{\left[\mathrm{T}-\left(\mathrm{T}_{\mathrm{Cv}}-33.3\right)\right]} \\
\left({ }^{\circ} \mathrm{C}\right)\end{array}$ & $\begin{array}{c}\mathrm{T}-\mathrm{NDT} \\
\left({ }^{\circ} \mathrm{C}\right)\end{array}$ & $\mathrm{K}_{\mathrm{Jc}}$ \\
\hline P2A & W1 & -30 & -56 & -70 & 95.9 \\
P2A & W2 & -30 & -56 & -70 & 178.7 \\
P2A & W3 & -30 & -56 & -70 & 147.9 \\
P2A & W4 & -30 & -56 & -70 & 118.2 \\
P2A & W5 & -30 & -56 & -70 & 129.5 \\
P2A & W6 & -30 & -56 & -70 & 170.4 \\
P2A & W7 & -30 & -56 & -70 & 194.0 \\
P2A & W8 & -30 & -56 & -70 & 102.3 \\
P4A & TC1 & -130 & -156 & -170 & 59.5 \\
P4A & TC2 & -130 & -156 & -170 & 85.1 \\
P4A & TC3 & -130 & -156 & -170 & 55.3 \\
P7A & TC9 & -130 & -156 & -170 & 56.4 \\
P4A & TC6 & -80 & -106 & -120 & 113.4 \\
P7A & TC10 & -80 & -106 & -120 & 51.3 \\
P13B & TC18 & -80 & -106 & -120 & 87.9 \\
P13B & TC21 & -10 & -36 & -50 & 211.1 \\
P13B & TC17 & -10 & -36 & -50 & 179.9 \\
P7A & TC14 & -10 & -36 & -50 & 171.8 \\
P7A & TC13 & -10 & -36 & -50 & 153 \\
P4A & TC7 & -10 & -36 & -50 & 156.8 \\
P4A & TC8 & -10 & -36 & -50 & 236.9 \\
P4A & TC5 & 0 & -26 & -40 & 269.3 \\
P7A & TC11 & 0 & -26 & -40 & 107.7 \\
P13B & TC19 & 0 & -26 & -40 & 277.8 \\
P4A* & TC4 & 23 & -3 & -17 & 325 \\
P7A* & TC12 & 23 & -3 & -17 & 328.4 \\
P13B* & TC20 & 23 & -3 & -17 & 277.4 \\
\hline & & & & & \\
\hline
\end{tabular}

*Full J-R curve 


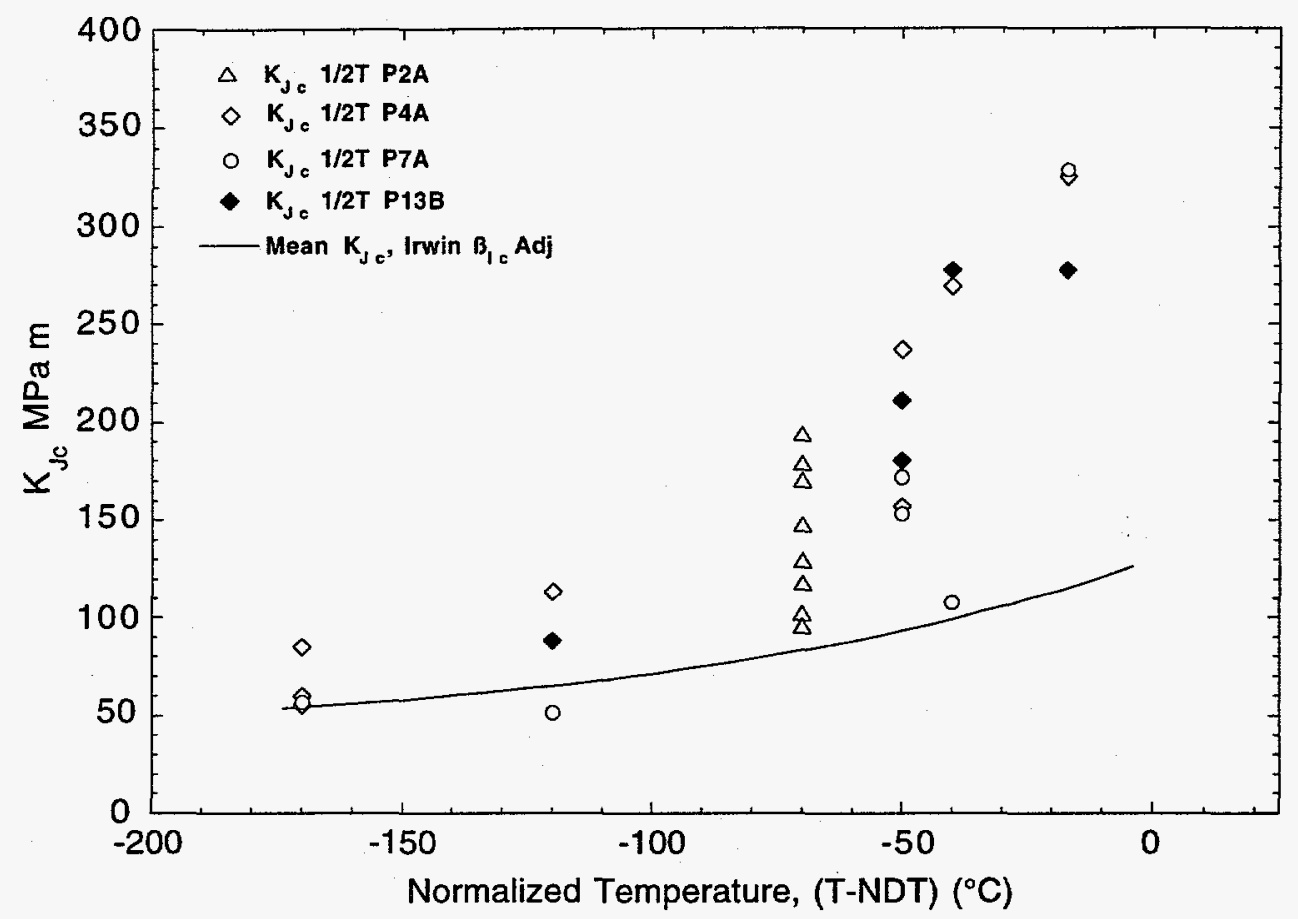

Fig. 8. Fracture toughness data from 1/2T compact tension specimens of heat-treated Plate 14 . "Mean" curve adjusted for full plane-strain conditions using the Irwin's $\beta_{\text {Ic }}$ equation is also shown.

loss-of-constraint at temperatures greater than NDT, which would be consistent with this observed experimental behavior.

The two methods used to interpret the $1 / 2 \mathrm{~T}$ data could then only be used to establish upper and lower bounds on what might be expected for shallow-flaw fracture toughness from the cruciform specimens of this heat-treated material. An interpretation of all the $1 / 2 \mathrm{~T}$ data and the results of the cruciform specimen tested at $\mathrm{T}=\mathrm{NDT}=40^{\circ} \mathrm{C}$ lead to the conclusion that, to obtain cleavage initiation tests (as compared to ductile tearing or plastic collapse tests) that exhibit biaxial loading effects, the cruciform testing should be performed at temperatures above $\mathrm{T}=-30^{\circ} \mathrm{C}\left(-22^{\circ} \mathrm{F}\right)$ but substantially less than $\mathrm{T}=40^{\circ} \mathrm{C}\left(104^{\circ} \mathrm{F}\right)$. The results of this conclusion and additional evaluation of constraint adjustments are discussed in the following section.

\section{Testing of Plate 14 Cruciform Specimens}

The six cruciform specimens tested at $-30^{\circ} \mathrm{C}\left(\mathrm{T}-\mathrm{NDT}=-70^{\circ} \mathrm{C}\right.$ ) provided a set of data for (a) three biaxial load ratios, and (b) two duplicate tests at each condition. The CMOD and LLD data for these specimens are shown in Figs. 9 and 10, respectively. Figure 9 compares the centerline 


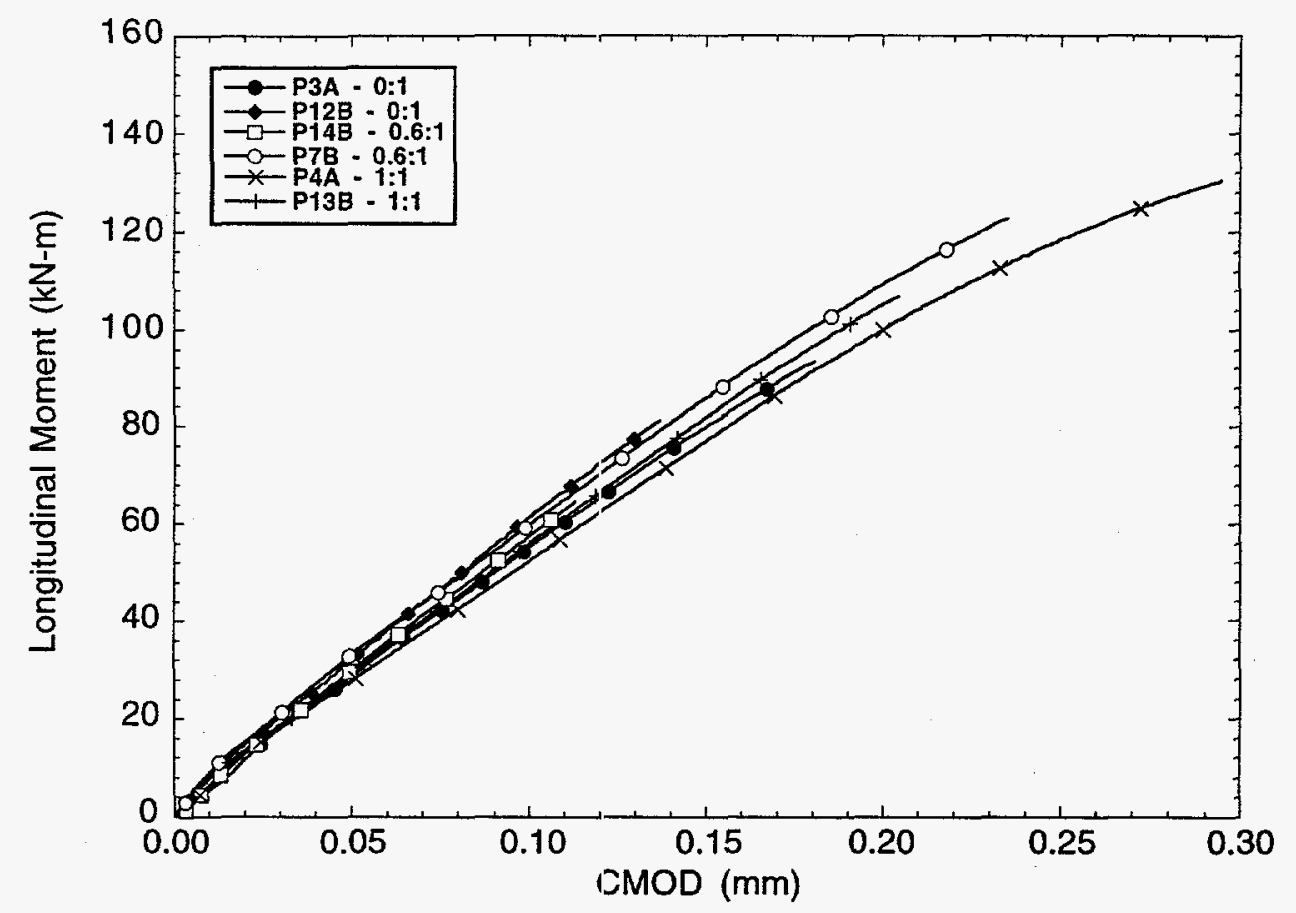

Fig. 9. Comparison of CMOD responses for cruciform specimens tested at $-30^{\circ} \mathrm{C}\left(-22^{\circ} \mathrm{F}\right)$ for load ratios of $0: 1,0.6: 1$, and $1: 1$.

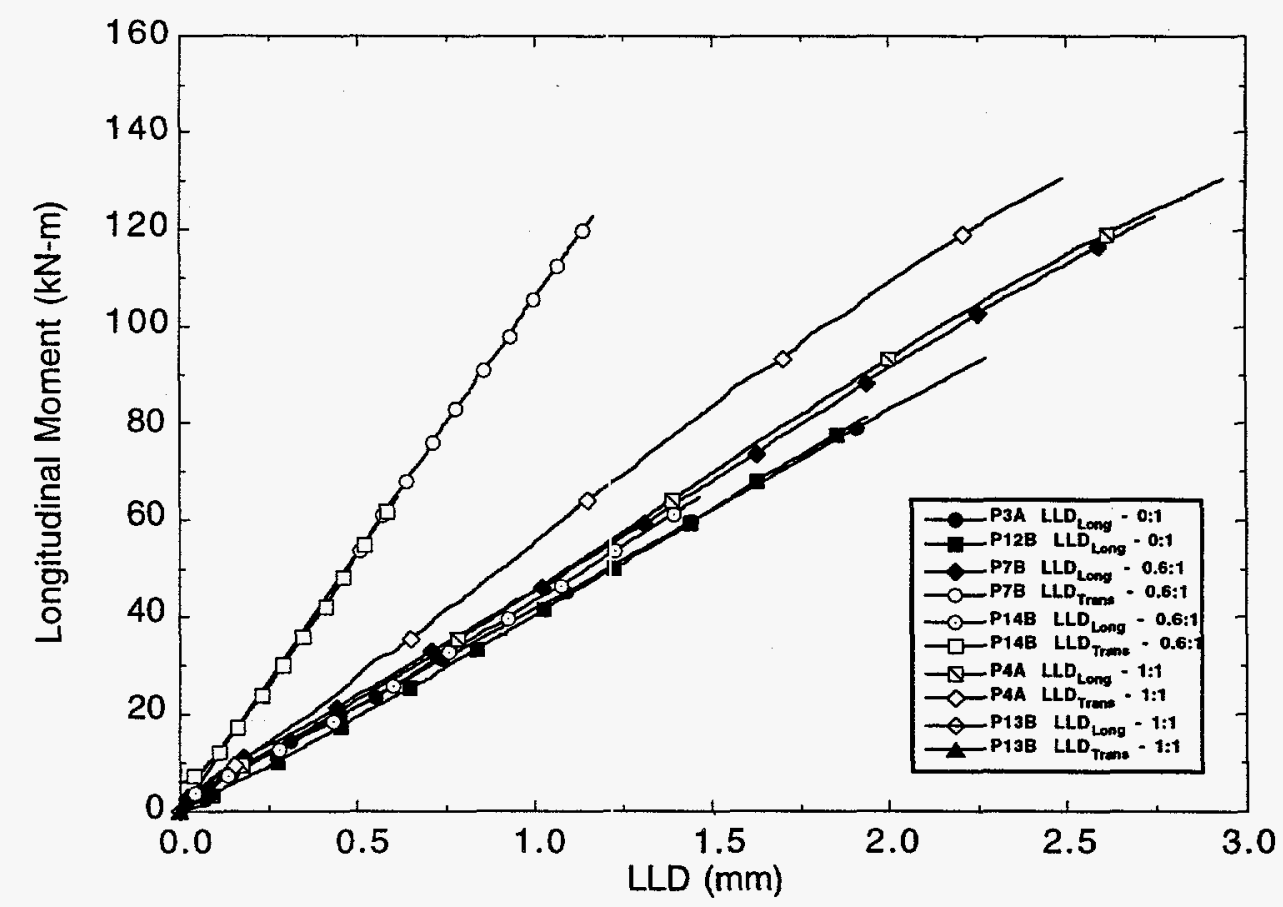

Fig. 10. Comparison of LLD responses for cruciform specimens tested at $-30^{\circ} \mathrm{C}\left(-22^{\circ} \mathrm{F}\right)$ for load ratios of $0: 1,0.6: 1$, and $1: 1$. 
CMOD for each of these six specimens. Figure 10 shows a comparison of the average LLD measured for the longitudinal and transverse beam arms for each test. Note that Specimens P3A and P12B were tested under uniaxial loading and no transverse beam arm LLD measurements were made.

The deformation response for all specimens was in good agreement. The specimens exhibited very little plastic deformation as measured by both CMOD and LLD regardless of the applied biaxial load. Variation of failure conditions, load and deformation (CMOD and LLD), seemed to vary randomly, i.e., there was no clear correlation between applied biaxial loading and failure load or deformation. Examination of the fracture surfaces showed that initiation occurred within the center 50-mm of flaw front, indicating that the cleavage initiation toughness values were not influenced by edge conditions. The fracture surface for Specimen P14B, 0.6:1 loading contained an inclusion in the flaw plane just below the machined flaw tip. The fatigue pre-crack was pinned by this inclusion, causing a non-uniform flaw front to be developed. The flaw depth at the deepest point was $13-\mathrm{mm}(0.51 \mathrm{in}$.) compared to $10-11-\mathrm{mm}$ for the other specimens in this group. This may have caused initiation at a lower load, with commensurate lower toughness as compared the other tests in this series.

The estimated toughness values for these specimens are shown in Table 4. Estimates were made using CMOD and LLD results, the measured crack depth at the probable initiation site, and the $\eta$-factor [19] procedures that have been used previously in estimating toughness from shallowflaw tests $[3,10]$. The values for all these tests are near the estimated lower shelf toughness for this material, which is consistent with the observed deformation behavior, i.e., elastic tests. For cases where basically elastic deformation occurs, biaxial loading would be expected to have little effect on constraint at the flaw tip, and thus little effect on toughness. The elastic response of these specimens gave indication that the test temperature might be too low, i.e., $-30^{\circ} \mathrm{C}$ was on or nearly on the lower shelf, to cause a biaxial loading effect.

A second set of six cruciform specimens was tested at a nominal test temperature of $-5^{\circ} \mathrm{C}\left(23^{\circ} \mathrm{F}\right)$ (normalized temperature $\mathrm{T}-\mathrm{NDT}=-45^{\circ} \mathrm{C}$ ). This higher temperature was expected to provide a better balance between cleavage behavior and accumulated plasticity at failure for evaluation of biaxial effects on toughness. To investigate this new choice of test temperature, two specimens each were tested under uniaxial (0:1) loading, biaxial (0.6:1) loading, and full biaxial (1:1) loading. The final test results are shown in Table 4. Deformation responses of longitudinal load vs. CMOD and longitudinal load vs. LLD results are shown in Figs. 11 and 12. The longitudinal load vs. CMOD traces for these specimens were comparable but the failure deformation exhibited a 
Table 4. Summary of heat-treated Plate 14 cruciform specimen test results

\begin{tabular}{|c|c|c|c|c|c|c|c|c|c|}
\hline \multirow[t]{2}{*}{ Spec. } & $\begin{array}{l}\text { Test } \\
\text { Temp. }\end{array}$ & $\begin{array}{c}\text { Biaxiality } \\
\text { Ratio }\end{array}$ & $\begin{array}{l}\text { Failure } \\
\text { Load }\end{array}$ & $\begin{array}{l}\text { Failure } \\
\text { LLD }\end{array}$ & $\begin{array}{l}\text { Failure } \\
\text { CMOD }\end{array}$ & $\begin{array}{l}\eta \text {-Factor } \\
\text { P-LLD }\end{array}$ & $\begin{array}{l}K_{\mathrm{J}} \text { from } \\
\text { P-LLD }\end{array}$ & $\begin{array}{l}\eta \text {-Factor } \\
\text { P- LLD }\end{array}$ & $\begin{array}{c}\mathrm{K}_{\mathrm{J}} \text { from } \\
\mathrm{P}-\mathrm{CMO} \\
\mathrm{D} \\
\end{array}$ \\
\hline & {$\left[{ }^{\circ} \mathrm{C}\left({ }^{\circ} \mathrm{F}\right)\right]$} & & $\begin{array}{c}{[\mathrm{kN}} \\
(\mathrm{kips})]\end{array}$ & $\begin{array}{l}{[\mathrm{mm}} \\
\text { (in.)] }\end{array}$ & $\begin{array}{l}{[\mathrm{mm}} \\
\text { (in.)] }\end{array}$ & & $\begin{array}{l}{[\mathrm{MPa} \sqrt{\mathrm{m}}} \\
(\mathrm{ksi} \text { in)] }\end{array}$ & & $\begin{array}{l}{[\mathrm{MPa} \sqrt{\mathrm{m}}} \\
(\mathrm{ksi} \text { in)] }\end{array}$ \\
\hline $\mathrm{P} 2 \mathrm{~A}^{3}$ & $38(100)$ & $0: 1$ & $\begin{array}{r}1785.2 \\
(401.3)\end{array}$ & $\begin{array}{c}29.561 \\
(1.1633)\end{array}$ & $\begin{array}{l}2.0269 \\
(.0798)\end{array}$ & $\mathrm{NA}^{*}$ & $\mathrm{NA}^{*}$ & $\mathrm{NA}^{*}$ & $\mathrm{NA}^{*}$ \\
\hline P12B & $-30(-22)$ & $0: 1$ & $\begin{array}{c}638.4 \\
(143.5)\end{array}$ & $\begin{array}{l}1.938 \\
(.0763)\end{array}$ & $\begin{array}{c}.1372 \\
(.0054)\end{array}$ & 4.197 & $\begin{array}{c}76.3 \\
(69.5)\end{array}$ & 5.705 & $\begin{array}{c}88.0 \\
(80.1)\end{array}$ \\
\hline P3A & $-31(-24)$ & $0: 1$ & $\begin{array}{c}736.1 \\
(165.5)\end{array}$ & $\begin{array}{c}2.276 \\
(.0896)\end{array}$ & $\begin{array}{r}.1753 \\
(.0069)\end{array}$ & 3.011 & $\begin{array}{c}97.2 \\
(88.4)\end{array}$ & 4.911 & $\begin{array}{l}103.0 \\
(93.7)\end{array}$ \\
\hline P14B & $-31(-24)$ & $0.6: 1$ & $\begin{array}{c}508.2 \\
(114.3)\end{array}$ & $\begin{array}{c}1.504 \\
(.0592)\end{array}$ & $\begin{array}{r}.1118 \\
(.0044)\end{array}$ & 6.877 & $\begin{array}{c}99.6 \\
(90.7)\end{array}$ & 6.217 & $\begin{array}{c}70.3 \\
(64.0)\end{array}$ \\
\hline P7B & $-30(-22)$ & $0.6: 1$ & $\begin{array}{c}965.8 \\
(217.1)\end{array}$ & $\begin{array}{c}2.802 \\
(.1103)\end{array}$ & $\begin{array}{r}.2362 \\
(.0093)\end{array}$ & 1.379 & $\begin{array}{r}129.2 \\
(117.6)\end{array}$ & 3.612 & $\begin{array}{r}136.3 \\
(124.0)\end{array}$ \\
\hline P13B & $-28(-18)$ & $1: 1$ & $\begin{array}{c}840.4 \\
(188.9)\end{array}$ & $\begin{array}{c}2.398 \\
(.0944 .)\end{array}$ & $\begin{array}{r}.2032 \\
(.0080)\end{array}$ & 2.693 & $\begin{array}{c}97.9 \\
(89.1)\end{array}$ & 4.547 & $\begin{array}{r}112.1 \\
(102.0)\end{array}$ \\
\hline P4A & $-29(-21)$ & $1: 1$ & $\begin{array}{l}1026.7 \\
(230.8)\end{array}$ & $\begin{array}{l}2.936 i \\
\left(.115 \epsilon^{\prime}\right)\end{array}$ & $\begin{array}{r}.2946 \\
(.0116)\end{array}$ & 0.892 & $\begin{array}{r}139.7 \\
(127.1)\end{array}$ & 3.265 & $\begin{array}{r}141.2 \\
(128.5)\end{array}$ \\
\hline P2B.1 & $-4(24)$ & $0: 1$ & $\begin{array}{l}1351.0 \\
(303.7)\end{array}$ & $\begin{array}{c}7.330 \\
(.2886)\end{array}$ & $\begin{array}{r}.7036 \\
(.0277)\end{array}$ & 0.436 & $\begin{array}{r}245.3 \\
(223.2)\end{array}$ & 3.428 & $\begin{array}{r}261.5 \\
(238.0)\end{array}$ \\
\hline P2B. 2 & $-3(26)$ & $0: 1$ & $\begin{array}{r}1504.4 \\
(338.2)\end{array}$ & $\begin{array}{l}13.774 \\
(.5423)\end{array}$ & $\begin{array}{l}1.4173 \\
(.0558)\end{array}$ & 0.343 & $\begin{array}{r}346.2 \\
(315.1)\end{array}$ & 3.177 & $\begin{array}{r}375.5 \\
(341.8)\end{array}$ \\
\hline $\mathrm{P} 9 \mathrm{~A}$ & $-3(26)$ & $0: 1$ & $\begin{array}{l}1529.0 \\
(343.7)\end{array}$ & $\begin{array}{l}14.57 .5 \\
(.5738)\end{array}$ & $\begin{array}{c}1.6916 \\
(.0666)\end{array}$ & 0.327 & $\begin{array}{r}354.3 \\
(322.5)\end{array}$ & 3.149 & $\begin{array}{r}394.5 \\
(359.1)\end{array}$ \\
\hline P3B & $-4(24)$ & $0.6: 1$ & $\begin{array}{r}1449.6 \\
(325.9)\end{array}$ & $\begin{array}{c}8.440 \\
(.3323)\end{array}$ & $\begin{array}{r}.7645 \\
(.0301)\end{array}$ & 0.323 & $\begin{array}{r}266.1 \\
(242.2)\end{array}$ & 3.223 & $\begin{array}{r}266.8 \\
(242.8)\end{array}$ \\
\hline P12A & $-6(21)$ & $0.6: 1$ & $\begin{array}{l}1349.4 \\
(303.4)\end{array}$ & $\begin{array}{c}5.923 \\
(.2332)\end{array}$ & $\begin{array}{r}.5715 \\
(.0225)\end{array}$ & 0.388 & $\begin{array}{r}212.5 \\
(193.4)\end{array}$ & 3.166 & $\begin{array}{r}223.6 \\
(203.5)\end{array}$ \\
\hline P6B & $-4(24)$ & 1:1 & $\begin{array}{l}1096.0 \\
(246.4)\end{array}$ & $\begin{array}{l}3.637 \\
(.1432)\end{array}$ & $\begin{array}{r}.3505 \\
(.0138)\end{array}$ & 0.685 & $\begin{array}{r}166.9 \\
(151.9)\end{array}$ & 3.126 & $\begin{array}{r}162.3 \\
(147.8)\end{array}$ \\
\hline P15A & $-4(25)$ & $1: 1$ & $\begin{array}{l}1072.6 \\
(241.1)\end{array}$ & $\begin{array}{c}3.424 \\
(.1348)\end{array}$ & $\begin{array}{r}.3150 \\
(.0124)\end{array}$ & 0.716 & $\begin{array}{r}155.9 \\
(141.6)\end{array}$ & 3.175 & $\begin{array}{r}153.9 \\
(140.1)\end{array}$ \\
\hline P4B & $6(42)$ & $1: 1$ & $\begin{array}{r}1118.5 \\
(251.5)\end{array}$ & $\begin{array}{l}4.651 \\
(.1831)\end{array}$ & $\begin{array}{c}.3353 \\
(.0132)\end{array}$ & 0.686 & $\begin{array}{c}183.2 \\
(166.7)\end{array}$ & 3.430 & $\begin{array}{c}167.5 \\
(152.5)\end{array}$ \\
\hline P6A & $4(40)$ & $0.6: 1$ & $\begin{array}{l}1255.1^{2} \\
(282.2)\end{array}$ & $\begin{array}{l}5.210 \\
(.2051)\end{array}$ & $\begin{array}{l}.4089 \\
(.0161)\end{array}$ & 0.444 & $\begin{array}{c}204.3 \\
(186.0)\end{array}$ & 3.384 & $\begin{array}{c}195.2 \\
(177.6)\end{array}$ \\
\hline P10A & $8(46)$ & $0.6: 1$ & $\begin{array}{l}1570.8 \\
(353.2)\end{array}$ & $\begin{array}{l}10.714 \\
(.4218)\end{array}$ & $\begin{array}{l}0.9042 \\
(.0356)\end{array}$ & 0.309 & $\begin{array}{l}308.1 \\
(280.4)\end{array}$ & 3.376 & $\begin{array}{l}298.3 \\
(271.5)\end{array}$ \\
\hline P7A & $15(60)$ & $1: 1$ & $\begin{array}{l}1303.7^{2} \\
(293.1)\end{array}$ & $\begin{array}{l}6.012 \\
(.2367)\end{array}$ & $\begin{array}{l}.6121 \\
(.0241)\end{array}$ & 0.611 & $\begin{array}{c}248.3 \\
(226.0)\end{array}$ & 3.444 & $\begin{array}{c}229.3 \\
(208.7)\end{array}$ \\
\hline
\end{tabular}


Table 4. (Cont'd)

\begin{tabular}{cccccccccc} 
P11A & $16(60)$ & $1: 1$ & $\begin{array}{l}1419.5^{2} \\
\text { P9B }\end{array}$ & $16(6.932$ & .5563 & 0.372 & 246.9 & 3.351 & 234.1 \\
& & & $(319.1)$ & $(.2729)$ & $(.0219)$ & & $(224.7)$ & & $(213.1)$ \\
P11B & $17(62)$ & $1: 1$ & $1456.5^{2}$ & 9.934 & 1.0897 & 0.584 & 352.8 & 3.585 & 325.5 \\
& & & $1500.9^{2}$ & 9.766 & .8204 & 0.334 & 294.7 & 3.397 & 281.9 \\
P10B & $-6(22)$ & $1: 1$ & $1246.2^{2}$ & 5.260 & .4801 & 0.616 & 230.2 & 3.377 & 204.6 \\
& & & $(280.2)$ & $(.2071)$ & $(.0189)$ & & $(209.5)$ & & $(186.2)$ \\
P15B & $-4(25)$ & $0.6: 1$ & $1431.1^{2}$ & 7.537 & .5791 & 0.332 & 248.1 & 3.227 & 232.4 \\
& & & $(321.7)$ & $(.2967)$ & $(.0228)$ & & $(225.8)$ & & $(211.5)$ \\
P13A & $-6(21)$ & $0: 1$ & $1165.1^{2}$ & 5.250 & .3912 & 0.785 & 217.3 & 4.831 & 184.2 \\
& & & $(261.9)$ & $(.2067)$ & $(.0154)$ & & $(197.8)$ & & $(167.6)$ \\
\hline
\end{tabular}

${ }^{1}$ Test discontinued, no cleavage.

${ }^{2}$ Failure load based on equivalent $254-\mathrm{mm}$ (10 in) beam arm length.

strong dependence on the applied biaxial load as shown in Fig. 11. The deformation trace of Specimen P2B is not anomalous. In testing Specimen P2B, the transverse beam arm reaction pistons, conventionally called the North and South reaction pistons, had not been retracted sufficiently and, at a total load near $1300 \mathrm{kN}$, came into contact with the transverse beam arm load seats. This caused a transition from uniaxial to low biaxial loading that was observed immediately at the display console. The test was interrupted, the specimen unloaded, and the fixture reconfigured. During this reconfiguration, the specimen temperature was maintained near $-5^{\circ} \mathrm{C}$. Posttest evaluation of the data indicated that the maximum biaxial-load ratio achieved was 0.16:1. Reload of this specimen exhibited little deviation from the initial longitudinal load vs. CMOD trace and from the longitudinal load vs. CMOD trace for Specimen P9A. It was concluded that the perturbation in load histogram would be insignificant so far as affecting the final toughness results.

The two load sequences for Specimen P2B have been identified as P2B.1, initial loading, and P2B.2, reload. The LLD traces shown in Fig. 12 include measurements for both the longitudinal and transverse beam arms (transverse beam arm LLD was not measured for uniaxial tests). The longitudinal LLD follows the same pattern as was observed for CMOD, Fig. 11, so far as the dependence of failure deformation on biaxial loading. It should be noted that, after testing specimens over the specified temperature range of interest, three additional specimens were tested at this same test temperature, one each under each load ratio. Three specimens at each biaxial load 


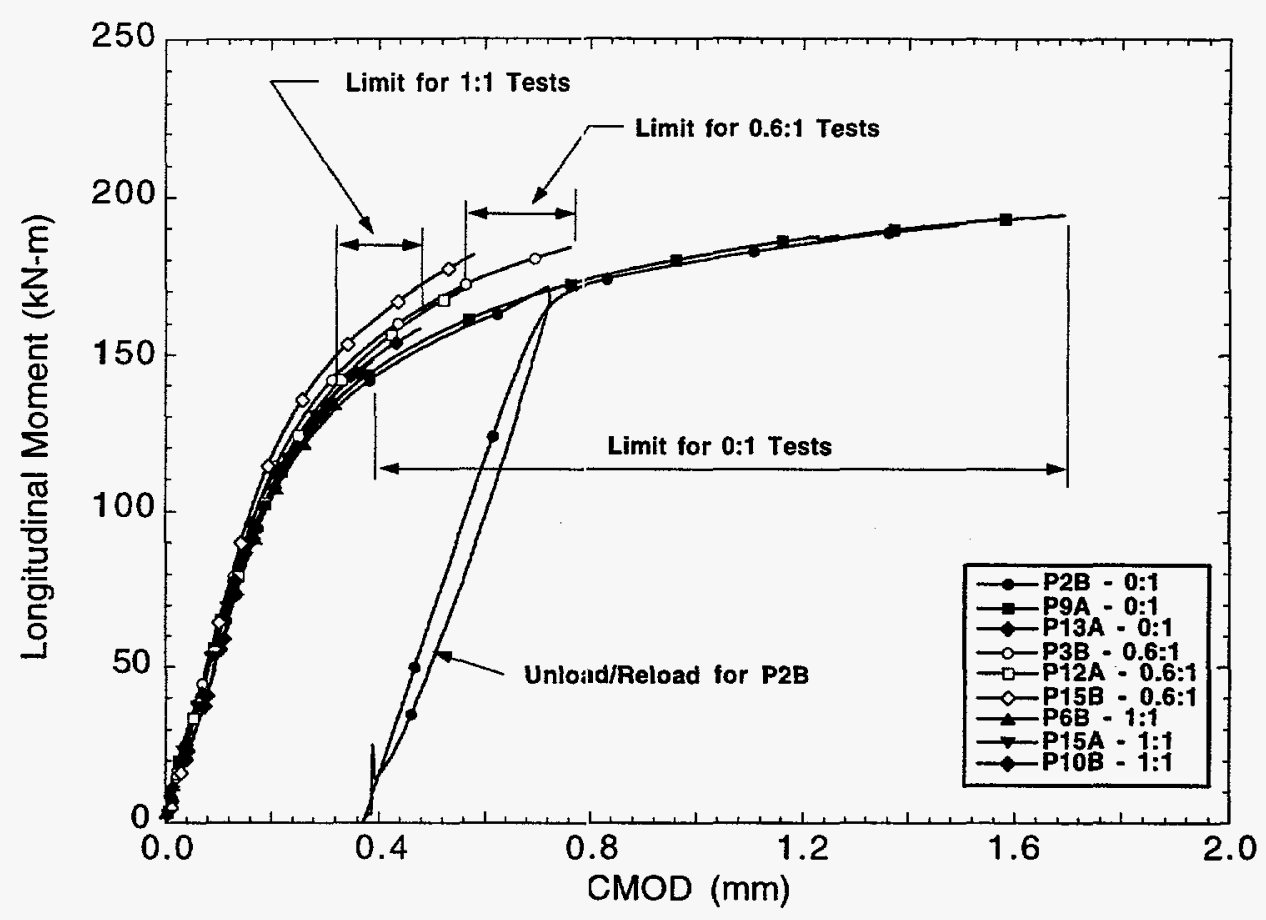

Fig. 11. Comparison of CMOD responses for cruciform specimens at nominal test temperature of $-5^{\circ} \mathrm{C}\left(23^{\circ} \mathrm{F}\right)$ for load ratios of $0: 1,0.6: 1$, and $1: 1$.

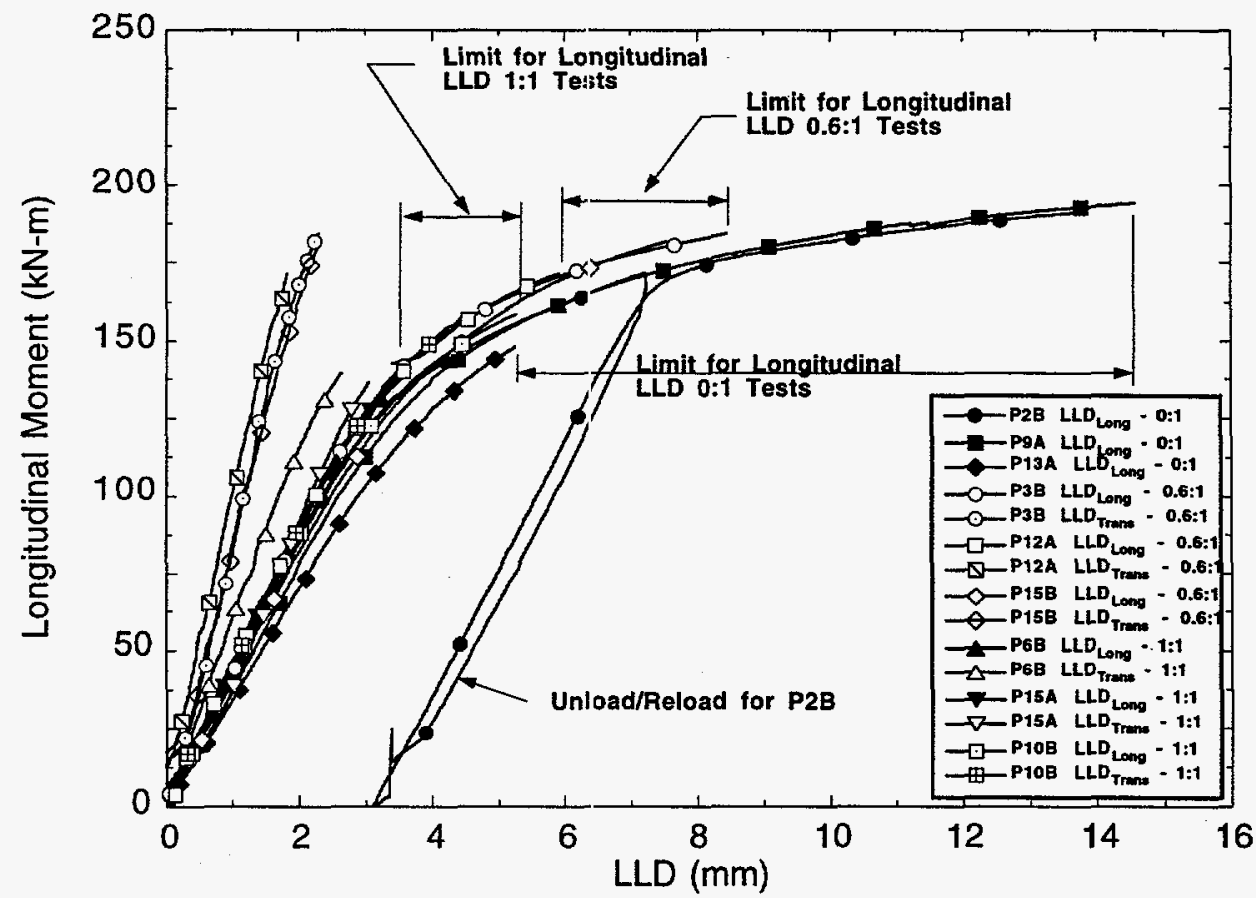

Fig. 12. Comparison of LLD responses for cruciform specimens at nominal test temperature of $-5^{\circ} \mathrm{C}\left(23^{\circ} \mathrm{F}\right)$ for load ratios of $0: 1,0.6: 1$, and $1: 1$. 
ratio at a single temperature were initially specified to provide a set that could be statistically evaluated. These results are also included in Figs. 11 and 12 and in Table 4.

The fracture behavior for these specimens characteristically involved substantial cracking of the test section. The type of cracking observed was dependent on the load biaxiality as can be seen in Figs. 13 and 14, which are posttest views of Specimen P3B (0.6:1) and Specimen P9A (0:1), respectively. On the top surface of the test section, fracture for the biaxially-loaded specimens was characterized by general cracking of the regions containing the load-diffusion-control slots (LDCS) at each side of the test section after initial cleavage initiation in the test flaw. This is thought to be caused by two factors, i.e., the sudden, additional longitudinal deformation applied to these regions when the central portion of the test section ceases to carry full load, and the presence of the applied transverse load. For the biaxially loaded specimen, when cleavage occurs, longitudinal load drops, longitudinal bending increases sharply, but transverse load remains high due to the elastic and inertia response of the specimen and load system. The LDCS ligaments are then highly stressed by sidewise bending and fracture at the stress concentrations of the LDCS ends. For the

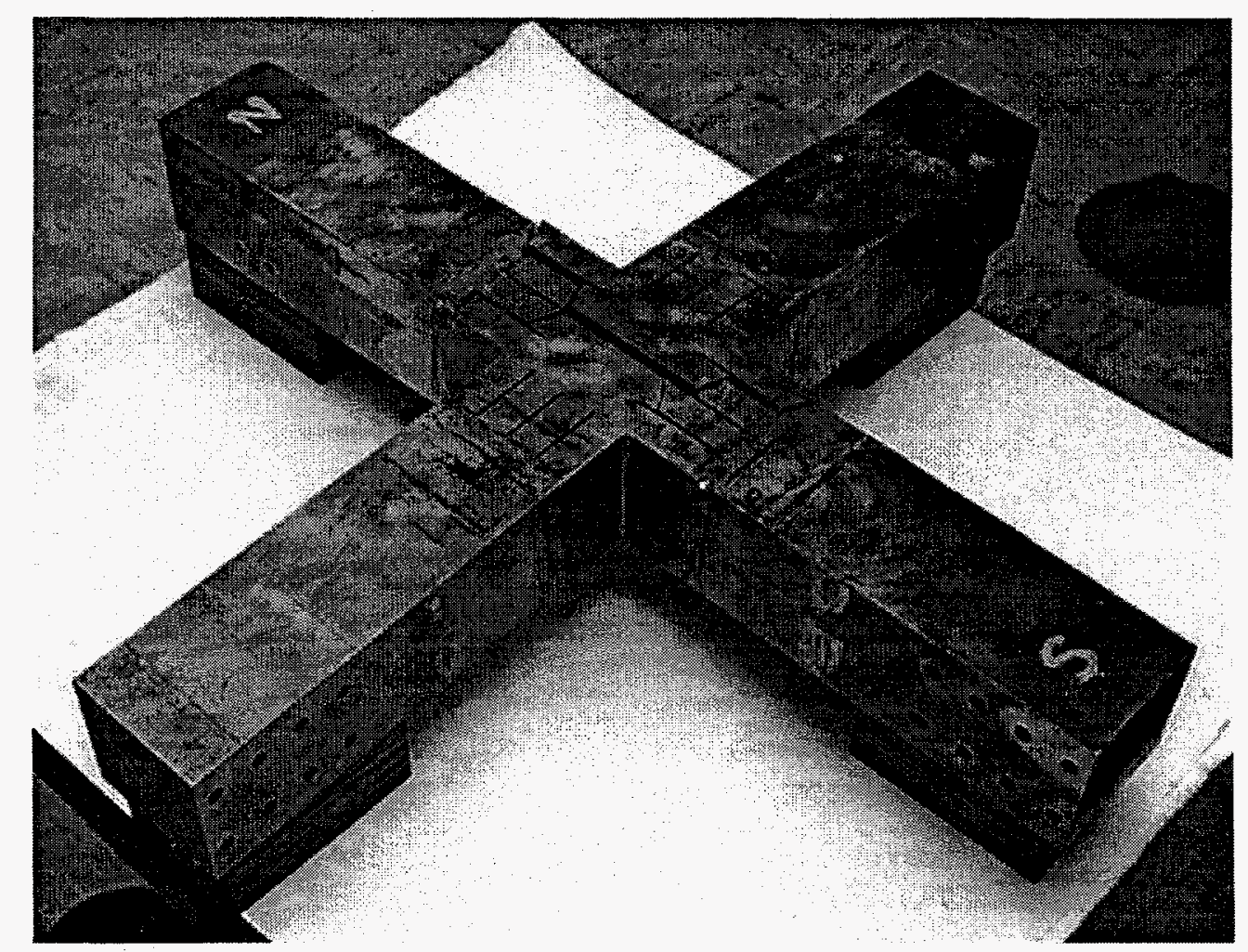

Fig. 13. Cruciform specimen after failure test under biaxial $(0.6: 1)$ loading at $-4^{\circ} \mathrm{C}\left(24^{\circ} \mathrm{F}\right)$. 


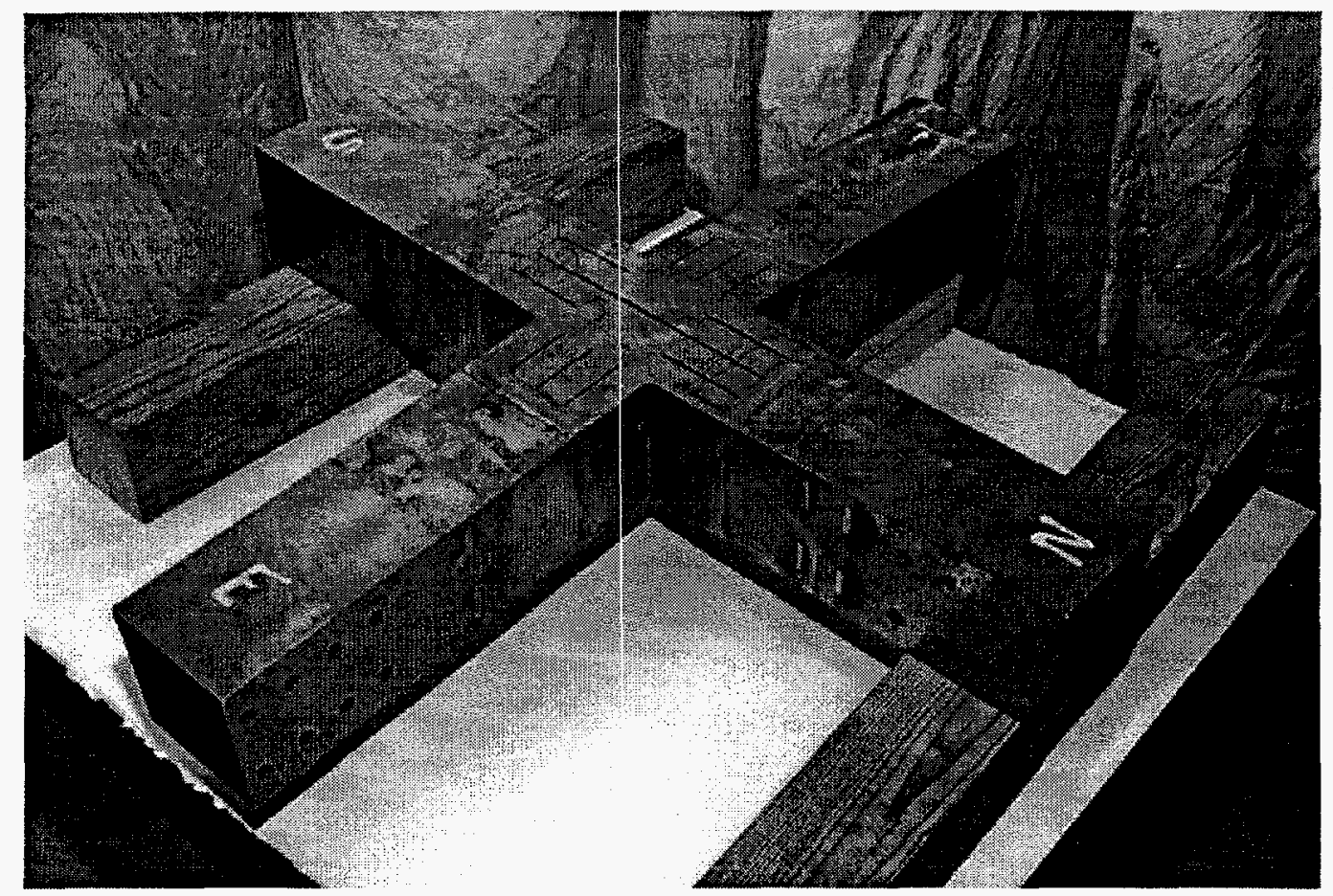

Fig. 14. Cruciform specimen after failure test under uniaxial $(0: 1)$ loading at $-3^{\circ} \mathrm{C}\left(26^{\circ} \mathrm{F}\right)$.

uniaxially loaded specimen, the lack of the trarisverse load subjects the LDCS ligaments to a much lower bending load and, subsequently, they do not fracture.

In addition to the surface cracking, crack propagation from the fatigue-precracked flaw tended to bifurcate in both the through-thickness and transverse directions, which is characteristic of a highenergy release fracture. The result was that most fracture surfaces were broken into more than two pieces, making interpretation of primary initiation site location more difficult. For those fracture surfaces providing a relatively uniform fracture surface, the primary initiation site was always within the center $50-\mathrm{mm}$ of the flaw front. Additional tests were performed at higher temperatures to investigate this behavior through the lower/mid-transition curve. The uniaxial tests at $-5^{\circ} \mathrm{C}$ indicated borderline plastic collapse, and no additional uniaxial specimens were tested at higher temperatures. Biaxial $0.6: 1$ and $1: 1$ tests were performed near $5^{\circ} \mathrm{C}$ and $15^{\circ} \mathrm{C}$ as shown in Table 4 . Although scatter in the data set increased, the clear distinction between the effect on toughness of different biaxial load ratios was retained. 


\section{Finite-Element Analyses of Cruciform Specimens}

Three-dimensional elastic-plastic fracture analyses were performed using the ABAQUS finiteelement program [20]. CMOD and LLD responses from these analyses provided $\eta$-factors for use in determination of fracture-toughness values for the cruciform specimen tests. Use of a highly refined crack-tip mesh also allows an evaluation of the development of stress fields and plastic strains around the flaw tip. These features are used in the evaluation of stress- and strain-based dual-parameter fracture models. Details of the model used may be found in Ref. 10.

It is important to achieve a reasonable match between the calculated and measured deformation response for the specimen. The primary impact for any lack of agreement between analysis and experiment is in the estimation of fracture toughness. The $\eta$-factor and $\mathrm{J}_{\mathrm{el}}$ at the test failure load are the two parameters taken from the analysis results for use in toughness calculations. The estimation of toughness is dominated by $\mathrm{J}_{\mathrm{el}}$ and the plastic area under the longitudinal load vs. CMOD (or LLD) curve. $J_{e l}$ will be unaffected if the elastic response of the analysis and the experiment are the same. Additionally, it was shown in Ref. 3 that the $\eta$-factor rapidly approaches an asymptotic value after the onset of plasticity. Thus, increases in plasticity result in only small changes in the $\eta$-factor. While good agreement between the predicted and measured specimen deformation behavior is desired for both FEA model validation and toughness calculations, exact agreement is not essential for the determination of reliable toughness values.

Analyses were conducted using temperature-dependent material properties taken from the tensile characterization tests performed. These properties represent the stress-strain behavior for this material over the range $-30^{\circ} \mathrm{C}<\mathrm{T}<20^{\circ} \mathrm{C}$, see Table 5. For the $-30^{\circ} \mathrm{C}$ tests, generally good agreement was obtained for the deformation response, which should be expected since the tests were basically elastic. It did appear, however, that the analyses over-predicted the stiffness of the specimen with this over-prediction being greatest for the biaxial 1:1 load case, see Fig. 15. For the tests performed at $-5^{\circ} \mathrm{C}$, good agreement was obtained between the $1: 1$ biaxial analytical and experimental results, while comparison of the uniaxial results showed the analysis to predict substantially stiffer longitudinal load vs. CMOD response than was measured, see Fig. 16. Here, since much more plasticity was accumulated, the comparison between analysis and experiment is somewhat exaggerated as compared to the results at $-30^{\circ} \mathrm{C}$. Underpredicting CMOD will lead to conservatively underpredicting toughness. A "stiff" model has been characteristic of the cruciform analyses. The approach has been to "soften" the stress-strain curve to more closely match the measured specimen deformation response. These revised analyses are currently underway and, based on previous experience, will result in only $2-3 \%$ changes in the estimated toughness values. 
Table 5. Properties used in finite-element analyses of heat-treated Plate 14 cruciform specimens

\begin{tabular}{|l|c|c|}
\hline \multirow{2}{*}{ Property } & \multicolumn{2}{|c|}{ Temperature } \\
\cline { 2 - 3 } & $-30^{\circ} \mathrm{C}\left(-22^{\circ} \mathrm{F}\right)$ & $-5^{\circ} \mathrm{C}\left(23^{\circ} \mathrm{F}\right)$ \\
\hline Young's Modulus [MPa (ksi)] & $182,720(26,500)$ & $182,720(26,500)$ \\
Poisson's Ratio & 0.25 & 0.25 \\
Proportional Limit [MPa (ksi)] & $534(77.5)$ & $512(74.2)$ \\
Ultimate Strength [MPa (ksi)] & $848(123)$ & $828(120.2)$ \\
\hline
\end{tabular}

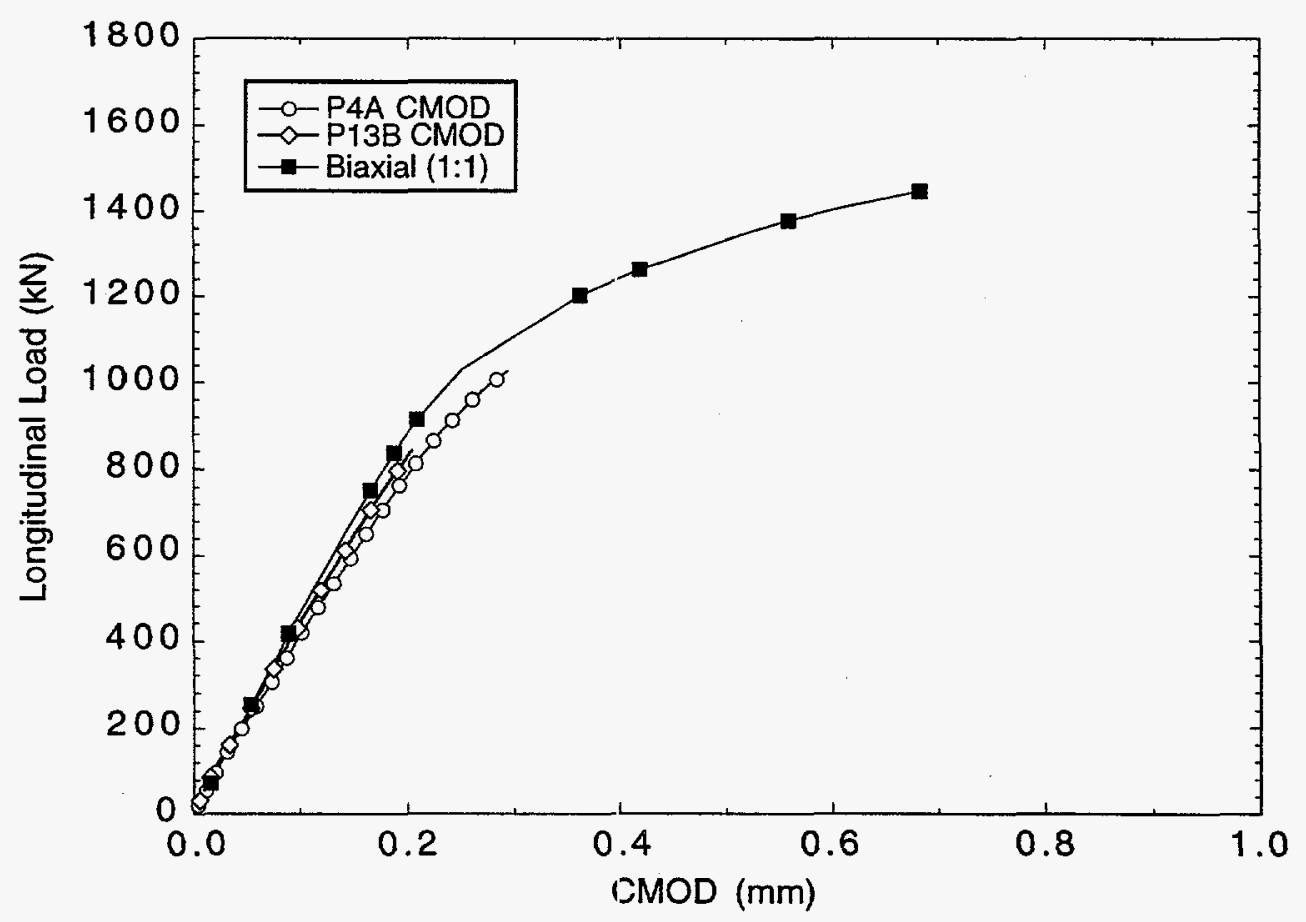

Fig. 15. Comparison of predicted and measured CMOD for biaxially (1:1) loaded cruciform test at $-30^{\circ} \mathrm{C}\left(-22^{\circ} \mathrm{F}\right)$. 


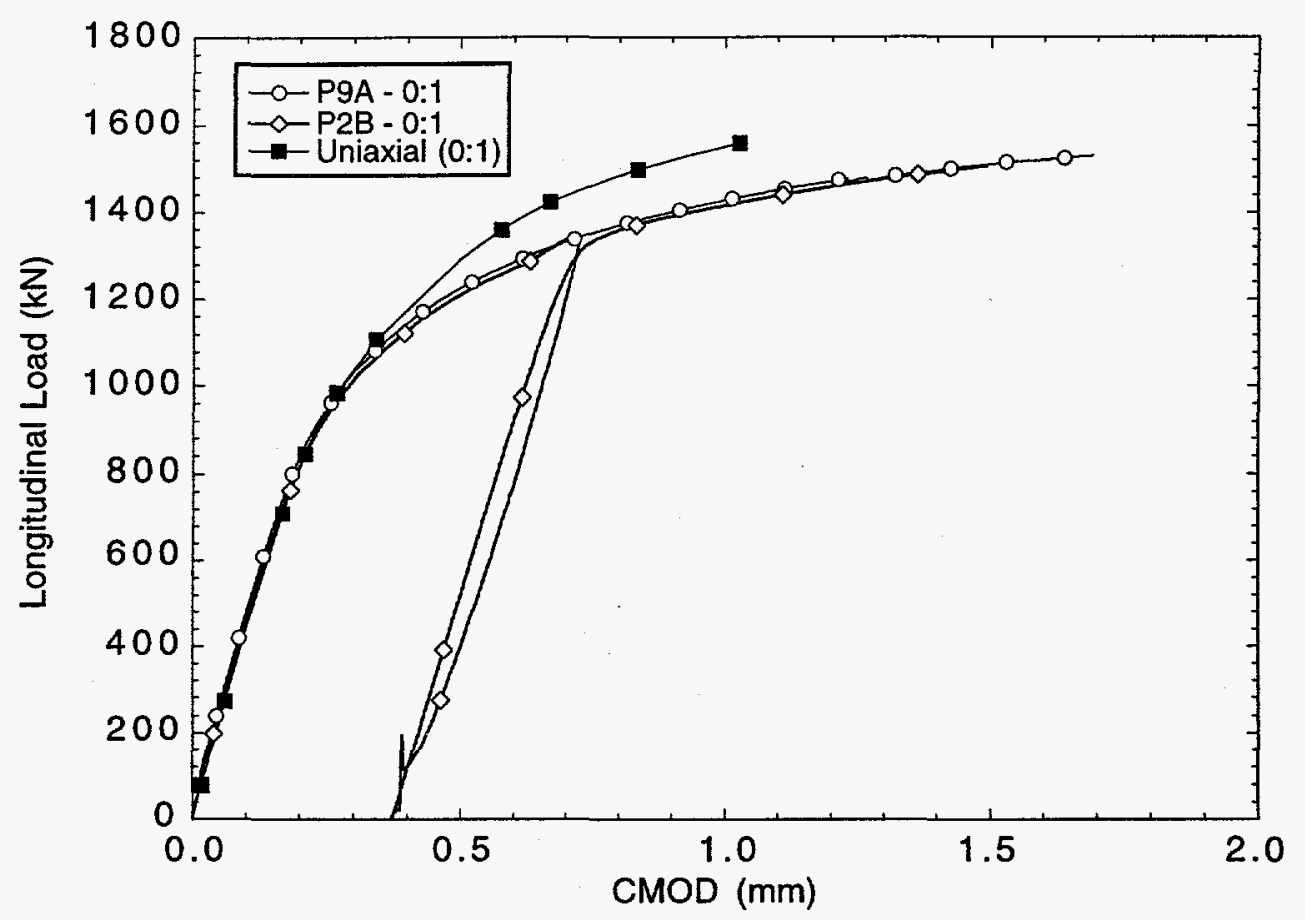

Fig. 16. Comparison of predicted and measured CMOD for uniaxially $(0: 1)$ loaded cruciform test at $-5^{\circ} \mathrm{C}\left(23^{\circ} \mathrm{F}\right)$.

\section{Biaxial Loading and Fracture Toughness}

These test results demonstrated a significant effect of biaxial loading on shallow-flaw fracture toughness. The estimated toughness values are shown graphically in Figs. 17 and 18 for the $-30^{\circ} \mathrm{C}$ and $-5^{\circ} \mathrm{C}$ test sets, respectively. The $-30^{\circ} \mathrm{C}$ specimens behaved in basically an elastic manner and little biaxial effect was observed. For the six specimens tested, the toughness increased slightly with an increase in biaxial ratio. Whether this is a real phenomenon or simply an artifact of the small data set is not known at this time. For this reason, a mean line is shown to represent the effect of biaxial loading on toughness at this temperature. Interpretation of this behavior currently is that additional specimens would show statistically no difference between uniaxial and biaxial loading.

For the tests performed at $-5^{\circ} \mathrm{C}$, the effect of biaxiality was pronounced as is shown in Fig. 18. In performing the additional three tests at $-5^{\circ} \mathrm{C}$, the two biaxial results agreed quite well with the prior tests. The additional uniaxial bend test, however, yielded an estimated toughness well below the mean of the previous two uniaxial tests. The mean value of the biaxial (1:1) loading resulted in 


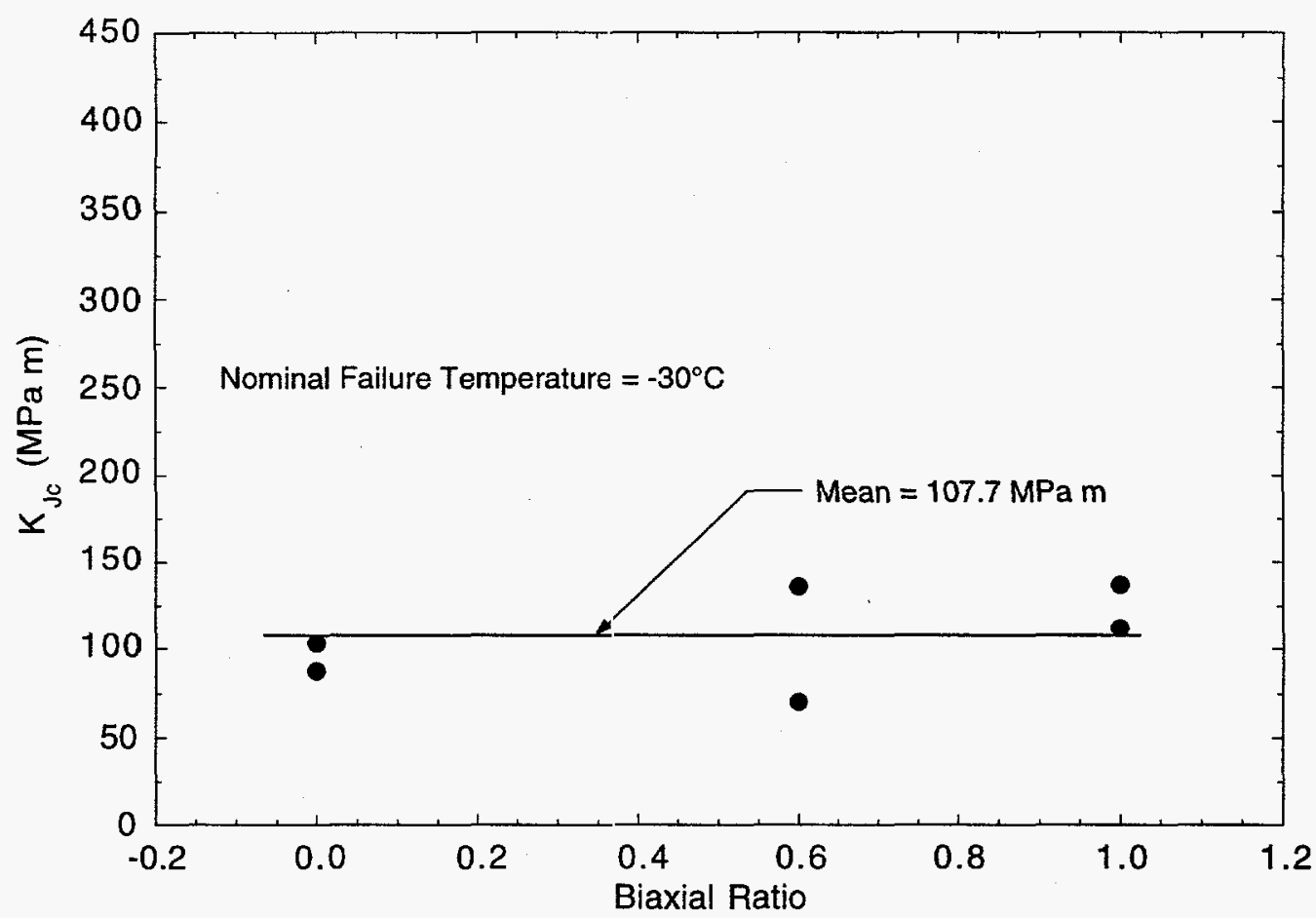

Fig. 17. The effect of biaxial load ratio on fracture toughness determined for heat-treated Plate 14 tested at $-30^{\circ} \mathrm{C}\left(-22^{\circ} \mathrm{F}\right)$.

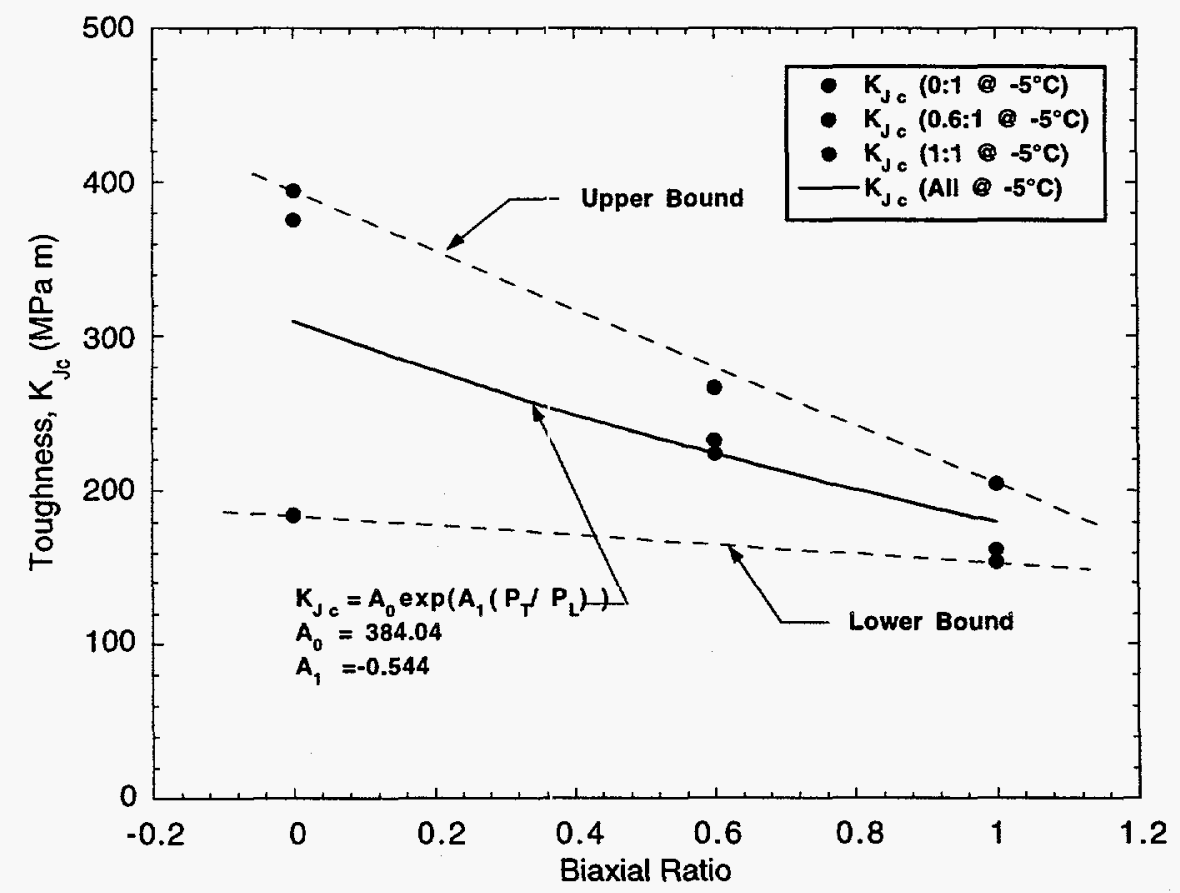

Fig. 18. The effect of biaxial load ratio on fracture toughness determined for heat-treated Plate 14 tested at $-5^{\circ} \mathrm{C}\left(23^{\circ} \mathrm{F}\right)$. 
approximately a $42 \%$ decrease from the mean uniaxial toughness $\left(\mathrm{K}_{\mathrm{JcB}} / \mathrm{K}_{\mathrm{JcU}}=0.58\right)$. One feature of these tests, also apparent in Figs. 17 and 18, is the lack of scatter for specimens tested under biaxial loading at comparable load and temperature conditions.

Figure 19 is a summary of all the cruciform data generated in this test series presented as a function of normalized test temperature $\left(\mathrm{T}-\mathrm{RT}_{\mathrm{NDT}}\right.$ ). The trend lines were constructed using both the $1 / 2 \mathrm{~T}$ CT data and the cruciform data. Use of the conventional normalizing parameters $\left(\mathrm{RT}_{\mathrm{NDT}}\right.$, NDT, or $\mathrm{T}_{\mathrm{CV}}$ ) did not provide a good correlation when these cruciform data were compared to both the previously developed shallow-flaw data [1] and the ASME Section XI $\mathrm{K}_{\mathrm{lc}}$ curve [21]. The Master curve parameter $T_{0}$, which has been proposed as an alternate method to normalize fracture toughness data sets [17], was also investigated. There is a rationale for a parameter of this type since it is based on static fracture initiation toughness data rather than on dynamic crack growth measurements. As was discussed earlier in this report, based on eight tests at a single temperature, $\mathrm{T}_{0}$ was estimated to be $-45.6^{\circ} \mathrm{C}$. A total of $271 / 2 \mathrm{~T}$ tests were performed over a range of temperatures from $-130^{\circ} \mathrm{C}$ up to $23^{\circ} \mathrm{C}$, with 24 of the 27 giving valid fracture toughness results.

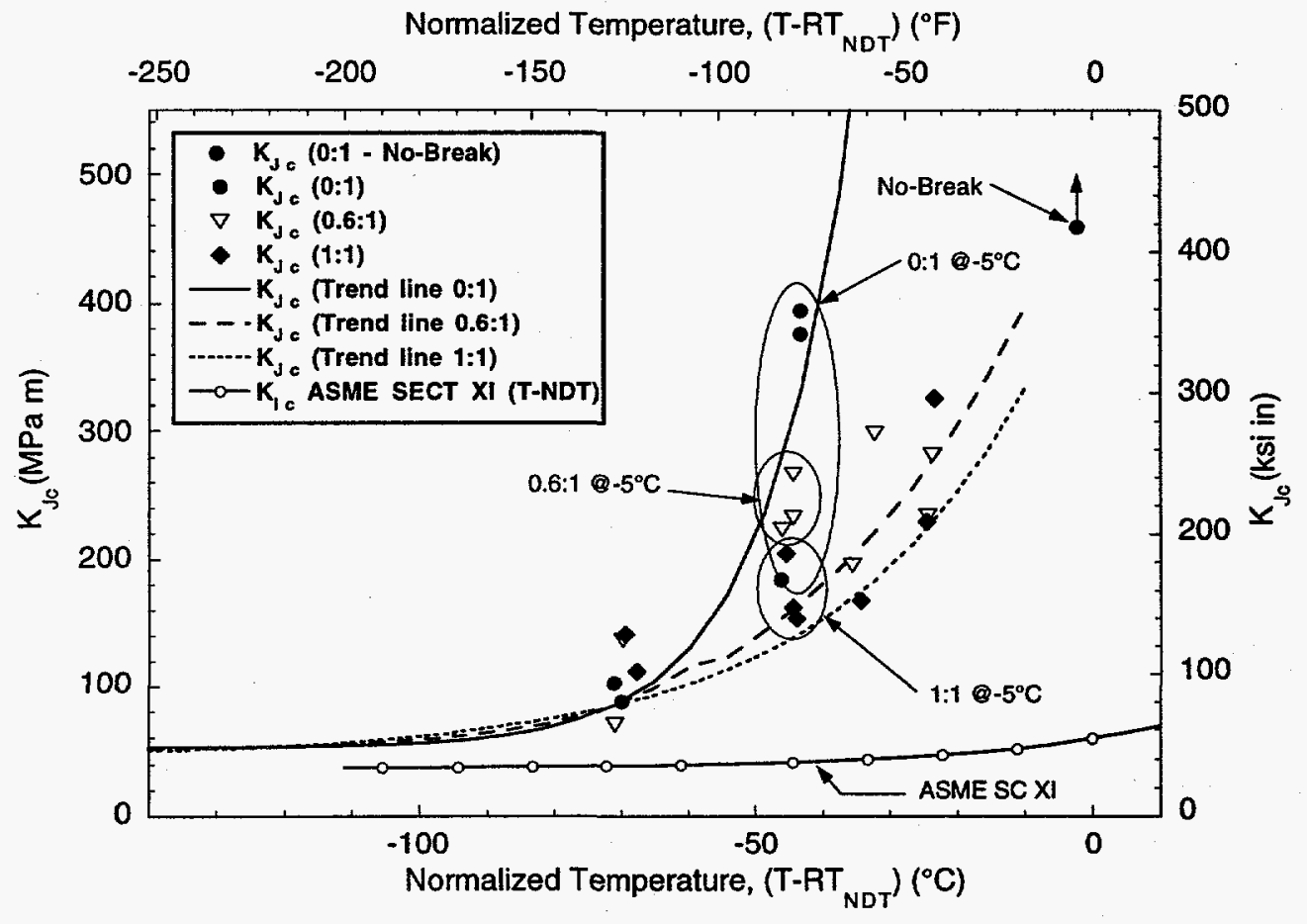

Fig. 19. A summary of all heat-treated Plate 14 cruciform data presented as a function of normalized ( $\mathrm{T}-\mathrm{RT}_{\mathrm{NDT}}$ ) test temperature. Trend curves fitted to data provide a visual interpretation of relationship between biaxial loading and temperature. 
Invalid results were from specimens that yielded full J-R curves without cleavage fracture. This larger data set of $1 / 2 \mathrm{~T}$ toughness values was adjusted to a $1 \mathrm{~T}$-constraint condition using,

$$
K_{1 T}=20+\left(K_{1 / 2 T}-20\right)(0.5 / 1)^{1 / 4}
$$

The data were then fitted using the Master curve equation [22].

$$
\mathrm{K}_{\mathrm{Jc}}(\mathrm{med})=30+70 \exp \left[0.019\left(\mathrm{~T}-\mathrm{T}_{0}\right)\right],(\mathrm{MPa} \mathrm{m})
$$

where $\mathrm{T}$ and $\mathrm{T}_{0}$ are in units of ${ }^{\circ} \mathrm{C}$. Evaluation of these data yielded a value of $\mathrm{T}_{0}=-37.3^{\circ} \mathrm{C}$ $\left(-35.1^{\circ} \mathrm{F}\right)$ as is illustrated graphically in Fig. 20. This value of $\mathrm{T}_{0}$ was used to normalize the data shown in Fig. 21 rather than the value of $\mathrm{T}_{0}=-45.6^{\circ} \mathrm{C}$ derived for the 8 specimens at a single temperature, as was discussed previously.

Normalization of the ASME Section XI lower-bound $\mathrm{K}_{\mathrm{lc}}$ curve was based on the analysis of the ASME Code data base performed by Nanstad, et al. [23]. Nanstad observed that the ASME SC XI lower-bound curve was controlled by the fracture toughness of HSST Plate 02 which has an $\mathrm{RT}_{\mathrm{NDT}}=-18^{\circ} \mathrm{C}\left(0^{\circ} \mathrm{F}\right)$. Using a data set of PCVN specimens tested in three-point slow bending and $1 T$ compact data for the HSST Plate 02 material, Sokolov, et al., determined the reference temperature for HSST Plate 02 to be $\mathrm{T}_{0}=-28^{\circ} \mathrm{C}\left(-18.4^{\circ} \mathrm{F}\right)$ [24]. Therefore, the value of $\mathrm{RT}_{\mathrm{NDT}}$ in the ASME equation [3],

$$
\mathrm{K}_{\mathrm{Ic}}=36.5+22.782 \exp \left[0.036\left(\mathrm{~T}-\mathrm{RT}_{\mathrm{NDT}}\right)\right]
$$

can the be replaced by $\mathrm{T}_{0}+28^{\circ} \mathrm{C}$ yielding

$$
\mathrm{K}_{\mathrm{Jc}}=36.5+22.782 \exp \left[0.036\left(\mathrm{~T}-\mathrm{T}_{0}-28\right)\right]
$$

where $\mathrm{T}, \mathrm{RT}_{\mathrm{NDT}}$, and $\mathrm{T}_{0}$ are in ${ }^{\circ} \mathrm{C}$ and $\mathrm{K}_{\mathrm{Ic}}$ is in MPa $\mathrm{Vm}$. The results of this adjustment to both the data and the ASME curve are apparent in Fig. 21. A substantially improved agreement is obtained between the Plate 14 biaxial data and the ASME curve using $T_{0}$ as compared to RT $_{\text {NDT }}$.

A preliminary interpretation of the effect of biaxial loading on fracture toughness can be derived from Fig. 21. Application of biaxial load results in an effective normalized temperature shift of the toughness curve generated using uniaxial date alone. This shift itself is temperature dependent being zero on the lower shelf and increasing to approximately $37^{\circ} \mathrm{C}$ at $\mathrm{K}_{\mathrm{Jc}}=400 \mathrm{MPa} \sqrt{\mathrm{m}}$. 


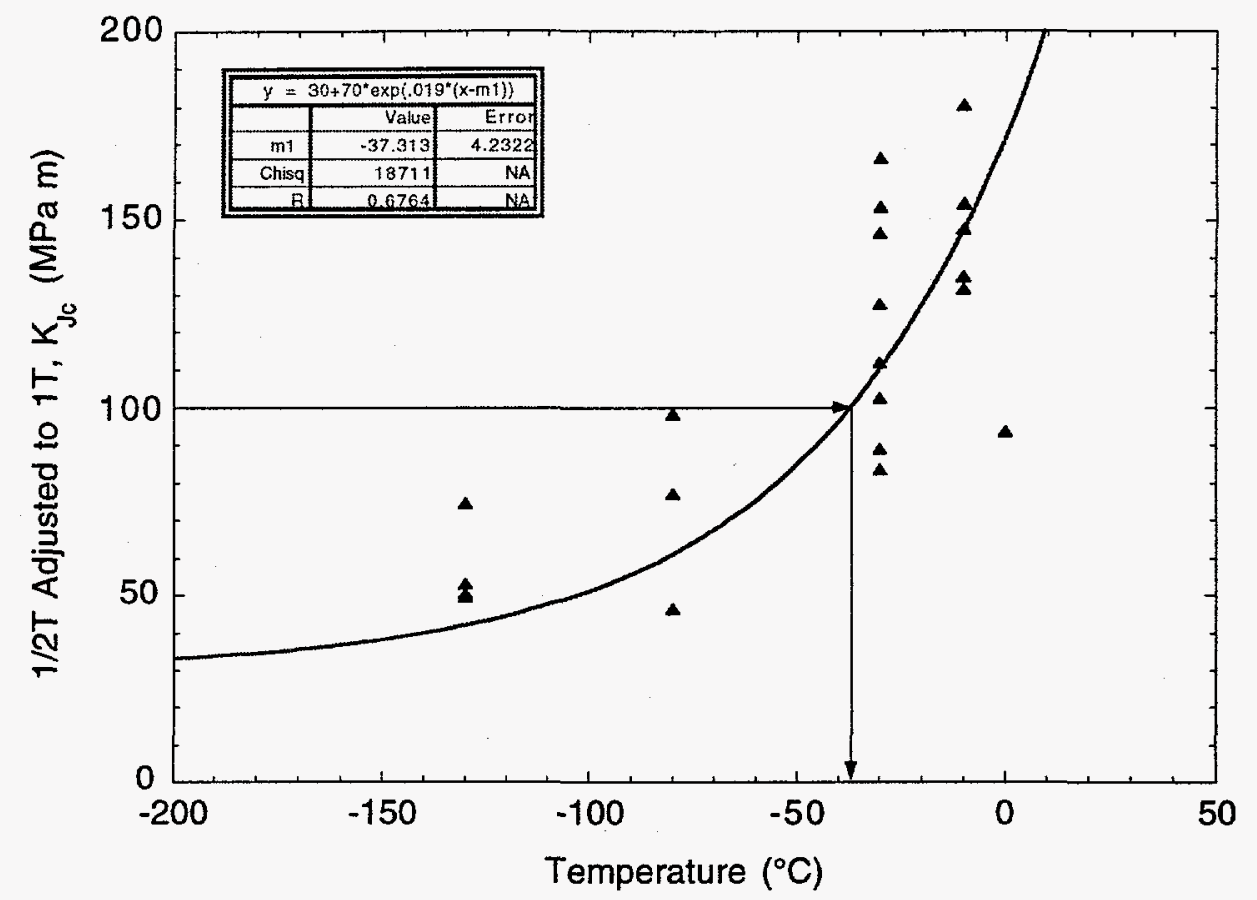

Fig. 20. Graphical representation of procedure used to determine $T_{0}$ from constraint adjusted 1/2T compact tension data for heat-treated Plate 14.

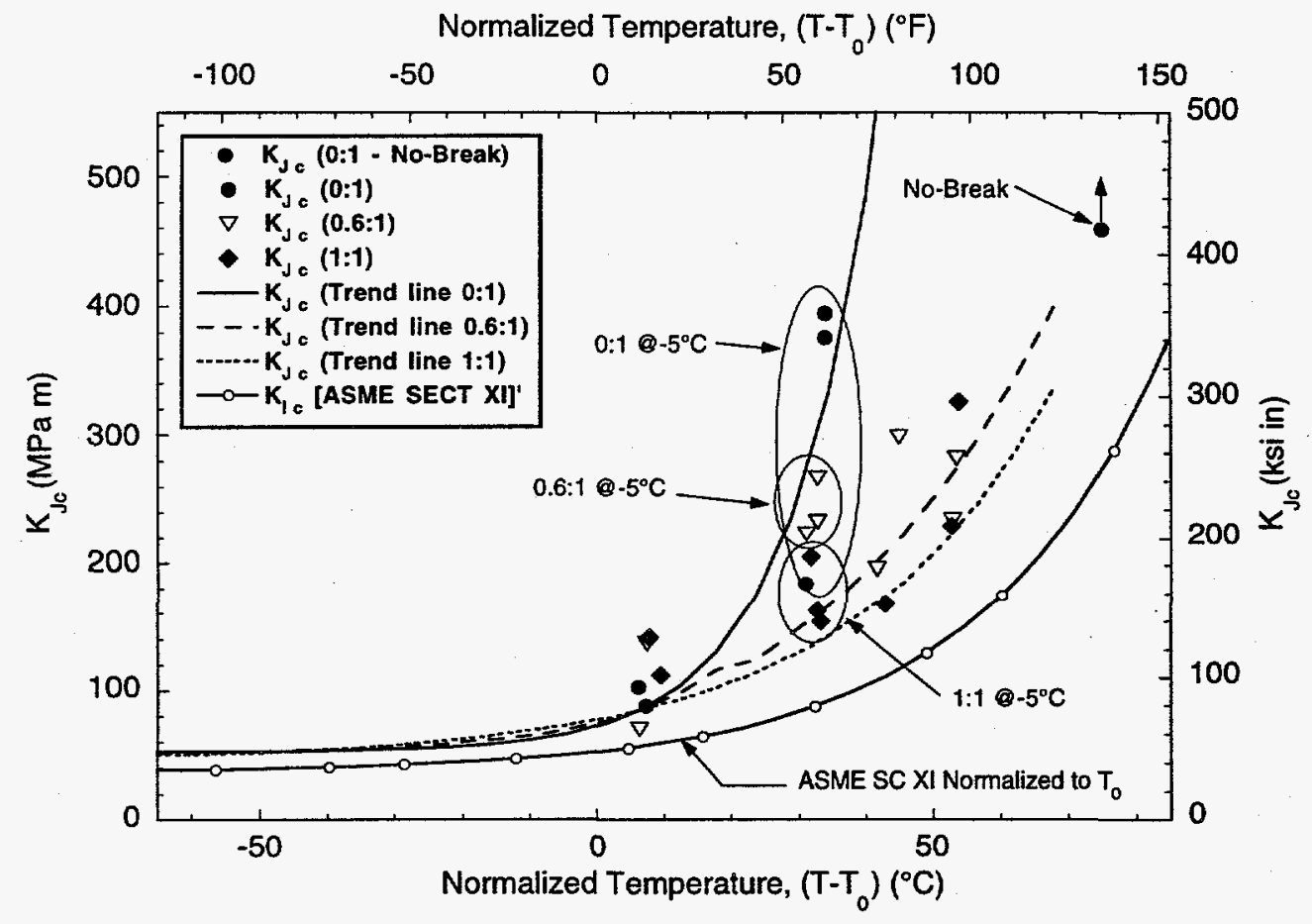

Fig. 21. A summary of all heat-treated Plate 14 cruciform data presented as a function of normalized $\left(T-T_{0}\right)$ test temperature. 
In Fig. 24, fracture toughness vs. biaxiality ratio data from the heat-treated HSST Plate 14 material tested near $\mathrm{T}-\mathrm{T}_{0}=34^{\circ} \mathrm{C}$ are compared with toughness data from clad-cruciform specimens fabricated from an RPV shell [12]. The clad specimens were tested in the temperature range $\left(\mathrm{T}-\mathrm{T}_{0}\right)$ from $7^{\circ} \mathrm{C}$ to $+12^{\circ} \mathrm{C}$, where $\mathrm{T}_{0}$ was estimated to be $-67.6^{\circ} \mathrm{C}$. For all biaxiality ratios, the toughness data from the RPV structural weld material are lower than that obtained from the high-yield strength Plate 14 material although the trend of reduction in toughness with increasing biaxiality ratio is retained. Of interest is that the ratio of the mean values of uniaxial-to-biaxial toughness for Plate 14 is 1.7 , while that for the RPV shell material is 1.75 even though the absolute toughness values vary significantly between the two materials. The lowest toughness value, obtained from a clad-cruciform beam specimen under full biaxial loading [12], is only slightly above the ASME Section XI fracture toughness curve $(\approx 6 \mathrm{MPa} \sqrt{\mathrm{m}})$. The results in Fig. 24 imply that biaxial loading is effective in reducing the fracture toughness of the relatively low-toughness clad/HAZ/structural-weld region of the RPV shell, as well as the high-toughness Plate 14 material.

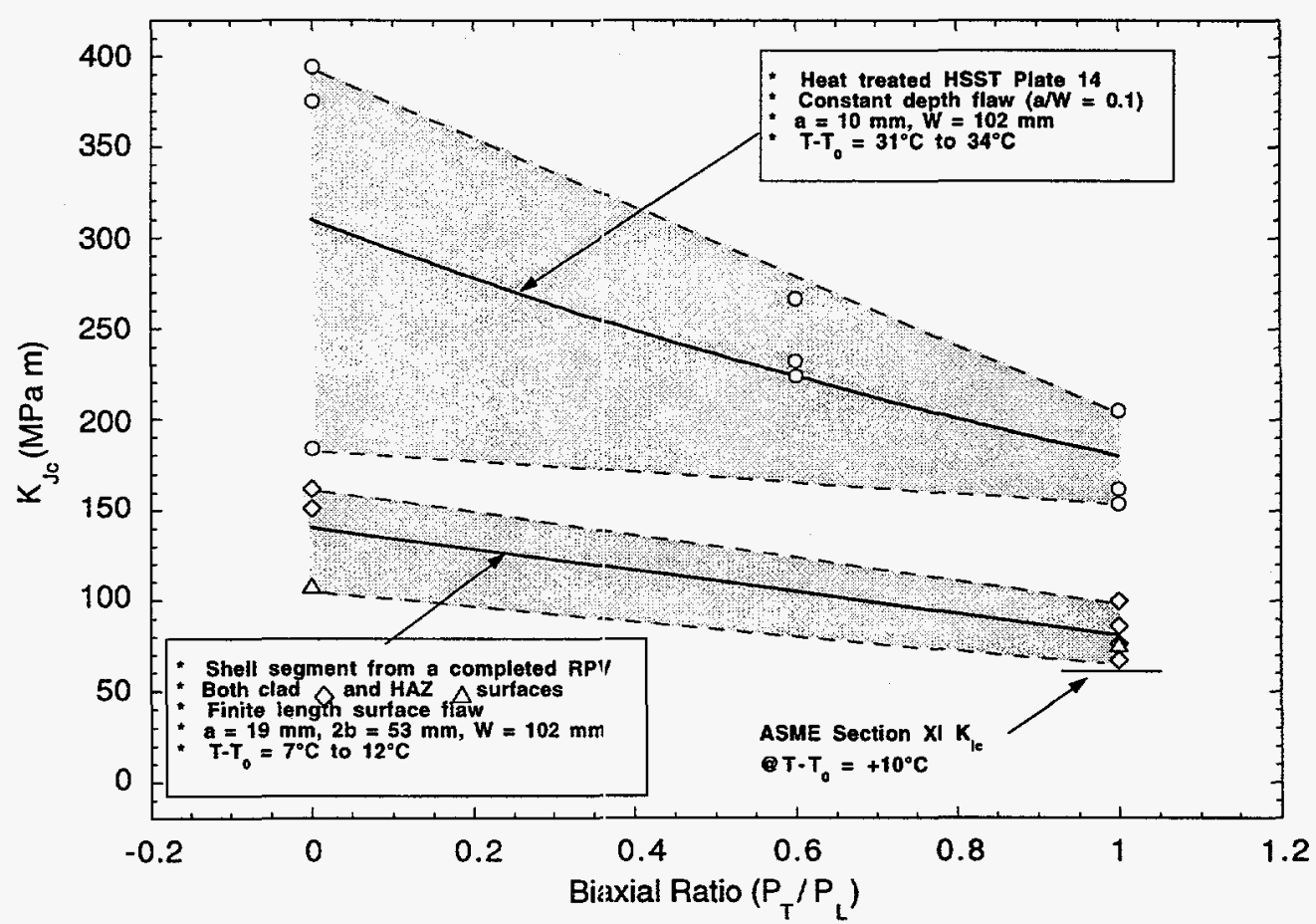

Fig. 24. Biaxial tests in (a) heat-treated A 533 B plate material with constant-depth shallowsurface flaws, and (b) typical RPV weld material with finite-length semi-elliptical surface flaws, show a consistent trend of decreasing fracture toughness with increasing load-biaxiality ratio. 


\section{Conclusion}

These tests demonstrate that biaxial loading can have a pronounced effect on shallow-flaw fracture toughness in the lower transition temperature region for RPV materials. For temperatures near the lower shelf, essentially no biaxial effect was observed. At a test temperature only $25^{\circ} \mathrm{C}$ higher, full biaxial (1:1) loading reduced toughness to approximately $58 \%$ of the average toughness obtained from uniaxial tests. For the small number of data points described herein, scatter in the estimated toughness values under biaxial loading was significantly reduced as compared to the scatter normally observed in conventional compact tension or single edge notch beam specimens. Under conditions where a biaxial effect was observed, biaxial loading also affected the deformation at failure as measured by both CMOD and LLD. Increasing the load biaxial ratio correlated with reducing the deformation at failure. The size constraint corrections for $1 / 2 \mathrm{~T}$ CT specimens did not predict the shape of the experimentally determined toughness curve through the lower transition temperature region. 


\section{References}

1. T. H. Theiss and D. K. M. Shum, Martin Marietta Energy Systems, Inc., Oak Ridge National Laboratory, "Experimental and Analytical Investigation of the Shallow-Flaw Effect in Reactor Pressure Vessels," USNRC Report NUREG/CR-5886 (ORNL/TM-12115), July 1992.

2. B. R. Bass, J. A. Keeney and W. J. McAfee, "Assessment of the Fracture Behavior of Weld Material from a Full-Thickness Clad RPV Shell Segment," PVP-Vol. 304, Fatigue and Fracture Mechanics in Fressure Vessels and Piping, ASME 1995, pp. 299-311.

3. T. J. Theiss et al., Martin Marietta Energy Systems, Inc., Oak Ridge National Laboratory, "Initial Results of the Influence of Biaxial Loading on Fracture Toughness," USNRC Report NUREG/CR-6132 (ORNL/TM-12498), January 1994.

4. D. Aurich et al., "The Influence of Multiaxial Stress States on Characteristic Parameters for Cleavage Fracture in the Elastic-Plastic Range," pp. 345-356 in Proceedings International Conference Applied Fracture Mechanics to Material and Structure, 1984.

5. W. E. Pennell, "Heavy-Section Steel Technology Program - Fracture Issues", pp. 255-264 in Journal of Pressure Vessel Technology, Vol. 114, August 1992.

6. D. K. M. Shum, J. G. Merkle, J Keeney-Walker, and B. R. Bass., "Analytical Studies of Transverse Strain Effects on Fracture Toughness for Circumferentially Oriented Cracks," NUREG/CR-5592 (ORNL/TM-11581), April 1991.

7. J. Keeney-Walker, "A Numerical Study of Local Crack-Tip Fields for Modeling Cleavage Fracture Initiation," Masters Thesis, The University of Tennessee, Knoxville, May 1990.

8. W. E. Pennell, "Heavy-Section Steel Technology Program: recent developments in crack initiation and arrest research," pp. 255-266 in Nuclear Engineering and Design, Vol. 142, 1993.

9. V. Weiss, "Material Ductility and Fracture Toughness of Metals," Proceedings of the International Conference on Mechanical Behavior of Materials, Hyoto, Japan, August 15-20, 1971, The Society of Materials Science, Japan, 1972.

10. W. J. McAfee, B. R. Bass, J. W. Bryson, and W. E. Pennell, Martin-Marietta Energy Systems, Inc., Oak Ridge National Lab., "Biaxial Loading Effects on Fracture Toughness of Reactor Pressure Vessel Steel," USNRC Report NUREG/CR-6273 (ORNL/TM-12866), March 1995.

11. W. E. Pennell, B. R. Bass, J. W. Bryson, Jr., T. L. Dickson and J. G. Merkle, "Preliminary Assessment of the Effects of Biaxial Loading on Reactor Pressure Vessel Structural-Integrity-Assessment Technology," Proceedings of 4th ASME/JSME International Conference in Nuclear Engineering, New Orleans, LA, March 10-14, 1996. 
12. B. R. Bass, W. J. McAfee, J. W. Bryson, Jr. and W. E. Pennell, "Determination of Cladding Effects on Shallow-Flaw Fracture Toughness of Reactor Pressure Vessel Steel under Prototypic Biaxial Loading", to be presented at the 5th International Conference on Nuclear Engineering, Nice, France, May 26-30, 1997.

13. The American Society of Mechanical Engineers Boiler and Pressure Vessel Code, Section II, "Materials Part A - Ferrous Material Specifications," pp. 831-835, Material Properties, American Society of Mechanical Engineers, New York, 1995.

14. W. J. McAfee and W. E. Pennell, "Development of Heat-Treating Specification for Surrogate Irradiated Base Material," pp. 5 in Heavy-Section Steel Technology Program Semiannual Progress Report for October 1994-March 1995, USNRC Report NUREG/CR-4219 (ORNL/TM-9593/V12\&N1), Vol. 12, No. 1, Oak Ridge National Laboratory, July 1996.

15. W. J. McAfee, "Material Characterization," pp. 7-12 in Heavy-Section Steel Technology Program Semiannual Progress Report for April-September 1995, USNRC Report NUREG/CR-4219 (ORNL/TM-9593/V12\&N2), Vol. 12, No. 2, Oak Ridge National Laboratory, January 1997.

16. R. K. Nanstad, et al., Martin-Marietta Energy Systems, Inc., Oak Ridge National Laboratory, Irradiation Effects on Fracture Toughness of Two High-Copper Submerged-Arc Welds, HSSI Series 5, USNRC Report NUREG/CR-5913 (ORNL/TM-12156/V1), October 1992.

17. D. E. McCabe, U. Zerbst, and J. Heerens, Development of Test Practice Requirements for a Standard Method of Fracture Toughness Testing in the Transition Range, GKSS Report 93/E/81, GKSS Forschungszentrum, Geesthacht, GmBH, Germany, 1993.

18. J. G. Merkle, "An Examination of the Size Effects and Data Scatter Observed in Small-Specimen Cleavage Fracture Toughness Testing," USNRC Report NUREG/CR-3672 (ORNL/TM-9088), Oak Ridge National Laboratory, April 1984.

19. M. T. Kirk and R. H. Dodds, Jr., "Experimental and Analytical Investigation of the Shallow-Flaw Effect in Reactor Pressure Vessels," NUREG/CR-5886 (ORNL/TM12115), July 1992.

20. ABAQUS Theory Manual, Version 5.3, (Hibbitt, Karlson, and Sorenson, Inc., Providence, Rhode Island, 1993).

21. The American Society of Mechanical Engineers Boiler and Pressure Vessel Code, Section XI, "Rules for Inservice Inspection of Nuclear Power Plant Components," Appendix A, "Analysis of Flaws," Article A-4000, Material Properties, American Society of Mechanical Engineers, New York, 1989.

22. J. G. Merkle and D. E. McCabe, "Development of an ASTM Test Method for Fracture Toughness in the Transition Regime," pp. 107 in Heavy-Section Steel Technology Program Semiannual Progress Report for October 1994-March 1995, USNRC Report NUREG/CR-4219 (ORNL/TM-9593/V12\&N1), Vol. 12, No. 1, Oak Ridge National Laboratory, July 1996. 
23. R. K. Nanstad, et al., Martin-Marietta Energy Systems, Inc., Oak Ridge National Laboratory, Preliminary Review of the Bases for the $K_{l c}$ Curve in the ASME Code, ORNL/NRC/LTR-93/15), July 1993.

24. M. A. Sokolov, et al., "Application of Small Specimens to Fracture Mechanics Characterization of Irradiated Pressure Vessel Steels," Fatigue and Fracture Mechanics: 28th Volume, ASTM ST'P 1321, J. H. Underwood, B. D. MacDonald, and M. R. Mitchell, Eds., American Society for Testing and Materials, 1997. 


\section{Internal Distribution}

1. D. J. Alexander

2-6. B. R. Bass

7-11. J. W. Bryson

12. W. G. Craddick

13. T. L. Dickson

14. D. M. Hetrick

15. M. A. Kuliasha

16-20. W. J. McAfee
21. D. E. McCabe

22. J. G. Merkle

23. R. K. Nanstad

24-28. W. E. Pennell

29. C. E. Pugh

30. T. M. Rosseel

31. P. T. Williams

32-35. Laboratory Records - RC

\section{External Distribution}

36. K. R. Wichman, EMCB/DE/NRR, U.S. Nuclear Regulatory Commission, Mailstop O7 D4, Washington, D.C. 20555-0001

37. E. M. Hackett, EMMEB/DET/RES, U.S. Nuclear Regulatory Commission, Mailstop T10 E10, Washington, D.C. 20555-0001

38. S. N. Malik, EMMEB/DET/RES, U.S. Nuclear Regulatory Commission, Mailstop T10 E10, Washington, D.C. 20555-0001

39. M. E. Mayfield, DET/RES, U.S. Nuclear Regulatory Commission, Mailstop T10 E10, Washington, D.C. 20555-0001

40-45. M. G. Vassilaros, EMMEB/DET/RES, U.S. Nuclear Regulatory Commission, Mailstop T10 E10, Washington, D.C. 20555-0001

46. C. Santos, EMMEB/DET/RES, U.S. Nuclear Regulatory Commission, Mailstop T10 E10, Washington, D.C. 20555-0001

47. R. L. Tregoning, Fatigue and Fracture Branch, Carderock Division, Naval Surface Warfare Center, 9500 McArthur Blvd., West Bethesda, MD 20817-5700

48. J. A. Joyce, U.S. Naval Academy, Mechanical Engineering Department, MS-11C, 590 Hollway Road, Annapolis, MD 21402

49. R. Dodds, 3140 Newmark Laboratory, 205 North Matthews, Urbana, Illinois 61801 